\title{
DELITOS SEXUALES CONTRA MENORES: ESPECIAL REFERENCIA A AGRESIONES Y ABUSOS SEXUALES
}

\author{
Ma Auxiliadora García Fernández \\ Profesora Sustituta de la Universidad de Almería \\ E-mail: auxigarcia1@gmail.com
}

\begin{abstract}
RESUMEN: Este trabajo pretende hacer un estudio sobre los delitos sexuales relativos a menores, en concreto, abusos y agresiones sexuales, dada la alarma social que en la actualidad provocan estos casos. Para ello, partimos, como no puede ser de otra manera, de su evolución histórico-legislativa, concretando la libertad sexual y la indemnidad sexual como bien jurídico protegido objeto de debate doctrinal y jurisprudencial, definiendo y conceptuando los distintos tipos recogidos en nuestro Código Penal y haciendo, por último, un análisis de las reformas que se pretenden de lege ferenda.
\end{abstract}

Palabras clave: Menores; agresión; abuso; libertad sexual; indemnidad sexual; jurisprudencia; reforma legislativa.

\begin{abstract}
This end of degree project aims to make a study on sexual crimes involving minors, specifically, sexual abuse and assault, given the social alarm that these cases have currently caused. To do so, we start, as it cannot be otherwise, from their historical-legislative evolution, specifying sexual freedom and sexual indemnity as the protected legal asset subject to doctrinal and jurisprudential debate, defining and conceptualizing the different criminal offences included in our Penal Code and, finally, making an analysis of the reforms that are intended de lege ferenda.
\end{abstract}

Keywords: Minors; assault; abuse; sexual freedom; sexual indemnity; jurisprudence; legislative reform.

Sumario: I. Introducción. II. EVolución HistóRich-Legislativa. III. Bien JuRídico Protegido. 3.1. Concepto Y Delimitación Del Bien JuRídico Protegido. 3.2. Debate Doctrinal: La Indemnidad Sexual. IV. Diferencia Esencial Entre Abuso, Agresión y Acoso Sexual: Tipos Delictivos Concernientes A Menores. 4.1. Referencia Al Concepto "Violencia E Intimidación" Como Elementos Diferenciadores Del Tipo. 4.2. Tipos delictivos concernientes a menores: abuso y agresión sexual. V. Análisis Del ANteproyecto Sobre Delitos SEXUALES DE LEGE FERENDA VI. Conclusiones Finales 


\section{INTRODUCCIÓN}

A lo largo de la historia, la sociedad en su conjunto ha buscado la protección de determinadas víctimas objeto de delitos dada su vulnerabilidad, es el caso de mujeres, menores o personas discapacitadas necesitadas de especial protección. Es cierto que existen determinados delitos que debido al bien jurídico atacado generan una mayor alarma social, hecho que, en definitiva, debe y viene a recoger el legislador; concretamente, nos referimos a los delitos que afectan a la libertad e indemnidad sexual de los menores.

En nuestro país, se ha producido en los últimos tiempos una evolución social, política y, sobre todo, tecnológica que lleva consigo la necesidad de cambios de carácter legislativo, en concreto, nos referimos a los delitos contra la libertad e indemnidad sexuales sobre los menores. En un primer momento, vamos a concretar ese desarrollo legislativo a lo largo de nuestro Derecho, dado que la historia de nuestras sociedades está en continuo avance y la aparición de nuevos hechos supone un constante reto que hemos de superar.

Todo ello conlleva la necesidad, como no puede ser de otra forma, de establecer la diferencia que existe entre cada uno de los delitos objeto de estudio; ya que es importante constatar los elementos que integran el tipo para poder delimitar la figura correspondiente, y con ello, si se adecúan las penas establecidas con los fines que nuestro ordenamiento prevé para ellas, en relación a la resocialización, prevención general y especial que buscan la reinserción de los autores de estos delitos en la sociedad.

Es importante que exista una coordinación y sintonía entre la creación de las normas y su aplicación directa, lo que el legislador crea debe estar en la misma línea que lo aplicado por los tribunales para que los ciudadanos confíen en el sistema judicial y se sientan protegidos, hecho que volvería a relacionarse con los fines de la pena ya mencionados. Esa aplicación directa pasa por el análisis y estudio de la Jurisprudencia en cuanto a las directrices que los tribunales marcan al dictar sentencias.

La necesidad del estudio de esta materia vendría dada por la protección del interés superior del menor y en función del bien jurídico protegido, ya que, en los últimos tiempos, hemos podido comprobar, especialmente a través de los medios de comunicación, el auge y proliferación de delitos dentro de este ámbito, que están creando una tremenda alarma social, provocando la aparición de corrientes neopunitivistas que claman a favor de la aplicación de penas más duras, caso de la prisión permanente revisable, para los autores de estos delitos. Estas corrientes provocan, en el ciudadano y en la sociedad, la necesidad de dar respuestas contundentes ante determinadas acciones delictivas que generan una enorme inseguridad y miedo, desplegando una política de "mano dura" ante cualquier individuo que rompa la paz social y ponga en peligro los más básicos principios de convivencia y seguridad. Políticas de intervención basadas en endurecimiento de penas, creación de nuevos tipos delictivos y control de delincuentes que limitan su reinserción y resocialización, menoscabando, sin más, las garantías primordiales y básicas de un Estado democrático de Derecho.

En definitiva, este trabajo pretende hacer una reflexión profunda sobre si la legislación está dando respuesta a lo que la sociedad demanda para su protección y el cuidado de los colectivos más vulnerables. 


\section{EVOLUCIÓN HISTÓRICA-LEGISLATIVA}

Tradicionalmente los delitos contra la libertad sexual se hallaban muy vinculados a conceptos de tipo religioso y moral, donde la víctima, principalmente mujer, debido a concepciones patriarcales, sufría un desamparo total, llegando a ser considerada como culpable del propio delito.

Desde el siglo XIX, los Códigos penales españoles, en concreto, desde el Código Penal de 1848, ya dedicaban un título a los delitos sexuales, bajo la rúbrica "Delitos contra la honestidad”. Queda claro que, en esos momentos, el bien jurídico protegido distaba mucho de proteger la libertad sexual de las personas, y menos aún, de mujeres y niños, pretendiendo salvaguardar su honra u honor.

No será hasta bien avanzado el siglo XX, cuando se produce la irrupción de corrientes pro derechos humanos, derechos del niño y adolescente, derechos de colectivos LGTBI (Lesbianas, Gays, Bisexuales, personas Transgénero e Intersexuales), etc., el momento en que la protección de la libertad sexual y la dignidad de la persona sufren un cambio radical.

Así, la Ley Orgánica (en adelante LO) 3/89, de 21 de junio, de actualización del Código Penal, cambia el título de "delitos contra la honestidad" por "delitos contra la libertad sexual”, con ello se hace un especial hincapié en la tutela del bien jurídico protegido: libertad e indemnidad sexual, dando relevancia a la protección del menor, tipificándose como delito los malos tratos ejercidos sobre menores o incapaces ${ }^{1}$.

Posteriormente, y como consecuencia de recomendaciones desde instancias europeas, en concreto de la Asamblea Parlamentaria del Consejo de Europa (Resolución 1099, de 25 de septiembre de 1996) y del Consejo de la Unión Europea, la Ley Orgánica 11/1999, de 30 de abril viene a modificar las recientes normas aprobadas en el Título VIII ("Delitos contra la libertad e indemnidad sexual"), Libro II del Código Penal de 1995, con la finalidad de dotar de una mayor protección a la integridad y libertad sexual de los menores e incapaces, específicamente mediante la reforma de los tipos delictivos de abuso sexual.

Más allá de nuestro propio ordenamiento jurídico, quizá convendría aplicar el principio de universalidad a los delitos de corrupción de menores o incapaces, dentro de los parámetros que la comunidad internacional reclama para proteger la libertad sexual de estas personas y sus derechos fundamentales inherentes a la dignidad, el derecho al libre desarrollo de la personalidad y la indemnidad o integridad sexual, en armonía con los derechos y libertades que la propia Constitución española garantiza, y defiende nuestro Tribunal Constitucional en reiterada Jurisprudencia.

En concreto, las modificaciones más significativas en esta reforma, entre otras, van referidas a los plazos de prescripción para que no empiecen a correr hasta el día en que la víctima alcance su mayoría de edad, a la necesidad de apreciar concurso real entre los delitos relativos a la prostitución y corrupción de menores y las agresiones o abusos sexuales, a la revisión del sistema de penas adecuándolo al principio de proporcionalidad y a las necesidades de la prevención general y especial, entre otras. ${ }^{2}$

1 Vid. «BOE» núm. 148, de 22 de junio de 1989. BOE-A-1989-14247.

2 Vid. «BOE» núm. 104, de 1 de mayo de 1999. BOE-A-1999-9744. 
La reforma legislativa realizada por LO 15/2003, de 25 de noviembre, de modificación del código penal, se concreta especialmente en la modificación del delito de pornografía infantil mediante el endurecimiento de las penas y la introducción de nuevos tipos delictivos como la pornografía infantil virtual ${ }^{3}$.

En el ámbito de los delitos sexuales, concretamente sobre menores, es importante referirnos a la transposición de la Decisión Marco 2004/68/JAI del Consejo, de 22 de diciembre de 2003, relativa a la lucha contra la explotación sexual de los niños y la pornografía infantil que incidirá en buena medida en la reforma operada por LO 5/2010 de 22 de junio, por la que se procede a la incorporación, en el Título VIII del Libro II del Código Penal, del Capítulo II bis denominado "De los abusos y agresiones sexuales a menores de trece años". Continuando con la línea iniciada por la reforma anterior, en cuanto a la excesiva utilización de nuevas tecnologías e internet con fines sexuales, se introduce un nuevo artículo 183 bis mediante el que se regula el, internacionalmente denominado, "child grooming”, el acoso sexual a menores a través de internet, previéndose además penas agravadas cuando el acercamiento al menor se obtenga mediante coacción, intimidación o engaño.

Del mismo modo, la transposición de dicha Decisión Marco incorpora a la regulación en el artículo 189.1 del Código Penal (en adelante CP), la captación de niños para que participen en espectáculos pornográficos, y en este mismo artículo, apartado 1.a), se incluye la conducta de quien se lucra con la participación de los niños en esta clase de espectáculos, penándose la conducta del cliente en aquellos casos en los que la relación sexual se realice con una persona menor de edad o incapaz.

Se considera necesario crear la pena de privación de la patria potestad, prevista en el Código civil, o instituciones análogas previstas en la legislación civil de las Comunidades Autónomas, que se incluye en el catálogo de penas privativas de derechos previstas en el artículo 39, fijándose su contenido en el artículo 46. Esta nueva pena tendrá el carácter de principal en los supuestos previstos en el artículo 192 y el de pena accesoria de acuerdo a lo establecido en los artículos 55 y 56, todos ellos del CP, cuando los derechos derivados de la patria potestad hubieren tenido una relación directa con el delito cometido ${ }^{4}$.

Es clara y manifiesta esa inquietud por la protección de los menores en cualquier ámbito, y así lo concreta nuestro legislador, en la última reforma del $\mathrm{CP}$, realizada por $\mathrm{LO}$ 1/2015 de 30 de marzo, por la que se vuelve a modificar el código penal, y avalada por la necesaria transposición de la Directiva 2011/93/UE, relativa a la lucha contra los abusos sexuales y la explotación sexual de los menores y la pornografía infantil y por la que se sustituye la anterior Decisión Marco 2004/68/JAI del Consejo, todo ello en consonancia con lo establecido en la Convención de las Naciones Unidas sobre los Derechos del Niño de $1989^{5}$ y la Carta de los Derechos Fundamentales de la Unión Europea ${ }^{6}$. En este sentido, se endurecen las sanciones penales en materia de lucha contra los abusos sexuales, la

3 Vid. «BOE» núm. 234, de 30 de septiembre de 2003. BOE-A-2003-18088.

4 Vid. «BOE» núm. 152, de 23 de junio de 2010. Referencia: BOE-A-2010-9953.

5 Vid. Convención de 20 de noviembre de 1989 sobre los Derechos del Niño, adoptada por la Asamblea General de las Naciones Unidas (Resolución 44/25), ratificado por España el 31 de diciembre de 1990: BOE núm. 313. Referencia BOE-A-1990-31312.

6 Vid. Diario Oficial de las Comunidades Europeas núm. 364, de 18 de diciembre de 2000. Referencia DOUE-Z-2000-70001. 
explotación sexual de menores y la pornografía infantil, destacando como novedad más importante, el que se eleve la edad del consentimiento sexual de los trece a los dieciséis años, ya que constituía una de las edades más baja de nuestro entorno ${ }^{7}$.

De esta manera, la realización de actos de carácter sexual con menores de dieciséis años será considerada, en todo caso, como un hecho delictivo, salvo que se trate de relaciones consentidas con una persona próxima al menor por edad y grado de desarrollo o madurez. Se establecen agravaciones si, además, concurre violencia o intimidación, o si los abusos consisten en acceso carnal por vía vaginal, anal o bucal, o introducción de miembros corporales u objetos por alguna de las dos primeras vías. En el caso de los menores de edad, menor de dieciocho años, pero mayores de dieciséis años, constituirá abuso sexual la realización de actos sexuales interviniendo engaño o abusando de una posición reconocida de confianza, autoridad o influencia sobre la víctima.

Por otra parte, se tipifica expresamente la conducta de hacer presenciar a un menor de dieciséis años actos o abusos sexuales sobre otras personas y se prevé la imposición, en estos casos, de penas de hasta tres años de prisión.

En los delitos contra la prostitución, se establece una separación más nítida entre los comportamientos cuya víctima es una persona adulta, de aquellos otros que afectan a menores de edad o a personas con discapacidad necesitadas de especial protección, se modifica el artículo 187 del CP con el objetivo de perseguir con mayor eficacia a quien se lucre de la explotación de la prostitución ajena.

Se presta especial atención al castigo de la pornografía infantil, de modo que se castigan los actos de producción y difusión, e incluso la asistencia a sabiendas a espectáculos exhibicionistas o pornográficos en los que participen menores de edad o personas con discapacidad necesitadas de especial protección. También se castiga el mero uso o la adquisición de pornografía infantil, y se incluye un nuevo apartado para sancionar a quien acceda a sabiendas a este tipo de pornografía por medio de las tecnologías de la información y la comunicación.

La protección de los menores se completa con un nuevo apartado en el artículo 183 ter del CP, destinado a sancionar al que a través de medios tecnológicos contacte con un menor de quince años y realice actos dirigidos a embaucarle para que le facilite material pornográfico o le muestre imágenes pornográficas ${ }^{8}$.

\section{BIEN JURÍDICO PROTEGIDO}

\subsection{Concepto y delimitación del bien jurídico protegido}

La Constitución Española ya establece la libertad como un derecho fundamental en su articulado, concretamente en el Capítulo II, "Derechos y Libertades", en su Sección 1", "De los derechos fundamentales y de las libertades públicas", convirtiéndose en el bien

7 MUÑOZ CUESTA, J. Y RUIZ DELAWARE ERENCHUN ARTECHE, E.: “Cuestiones prácticas sobre la reforma penal de 2015”. Ed. Aranzadi. Navarra 2015, p. 135.

8 Vid. «BOE» núm. 77, de 31 de marzo de 2015. Referencia: BOE-A-2015-3439. 
jurídico protegido en numerosos delitos, en nuestro caso, también en los delitos de abusos y agresiones sexuales.

En alusión a lo anteriormente manifestado, hemos de concretar que no es hasta la LO 3/89, de 21 de junio, que cambia el título de "delitos contra la honestidad" por "delitos contra la libertad sexual", cuando se determina ese bien jurídico protegido: libertad e indemnidad sexual, dando relevancia a la protección del menor ${ }^{9}$. Libertad, entendida como la capacidad de cualquier persona adulta de decidir si desea o no mantener relaciones sexuales, protegiendo, indirectamente, los derechos inherentes a la dignidad de la persona y el derecho al libre desarrollo de la personalidad en materia sexual ${ }^{10}$.

Además, advertimos que el Código Penal amplia ese bien jurídico protegido aludiendo al concepto de "indemnidad sexual", entendida como el derecho que corresponde a toda persona a no sufrir daño, físico o moral, como consecuencia de estas actividades. De esta forma, podemos entender que la palabra daño, en estos casos, lleva aparejada un plus de violencia que permite solicitar, no sólo, la pertinente indemnización por daños físicos, en el caso que los hubiere, sino también por daños morales y psicológicos que indudablemente llevan aparejadas estas conductas delictivas, conductas que de ser consentidas perderían todo carácter delictivo.

Es manifiesto que en determinados delitos donde la víctima es especialmente vulnerable, como es el caso de los menores, haya una necesidad implícita y a su vez demandada socialmente de ampliar ese bien jurídico para incluir el bienestar psíquico del menor, sin que el legislador, nacional o europeo, tenga la menor intención de inferir en su desarrollo personal y sexual ${ }^{11}$.

Se trata de delitos dolosos, donde el autor pretende satisfacer sus deseos sexuales a través de conductas que buscan agredir sexualmente a las víctimas, es lo que la Jurisprudencia denomina "ánimo lúbrico o libidinoso", evidenciando la voluntad de realización del delito ${ }^{12}$.

9 En este sentido, el Tribunal Supremo entiende que: "el bien jurídico no es la honestidad ni la intimidad de la persona, sino la libertad sexual de todo ser humano, como insalvable y privativa facultad de la persona de consentir o rechazar un contacto sexual de la naturaleza que sea". STS, Sala de lo Penal, nº 935/2006, de 02/10/2006, Rec 1593/2005, Ponente: Berdugo Gomez De La Torre, Juan Ramon.

10 Vid. ht t p s : / / w w w gu a s jurdicas.es/Content/Documento. a spx?param s=H 4 s I A A A A A A E A M M S b F 1 j TA A A U M I w s T tb L U o L L DzbsMz01LySVABaeFWPIAAAAA==WKE: "Delitos contra la libertad e indemnidad sexuales".

11 En este sentido, el Considerando no 20 de Directiva 2011/93/UE del Parlamento Europeo y del Consejo de 13 de diciembre de 2011, relativa a la lucha contra los abusos sexuales y la explotación sexual de los menores y la pornografía infantil, especifica que: "no regula las políticas de los Estados miembros con respecto a los actos de carácter sexual consentidos en los que pueden participar los menores y que pueden considerarse como el descubrimiento normal de la sexualidad en el proceso de desarrollo personal, habida cuenta de las diferentes tradiciones culturales y juridicas y de las nuevas formas de entablar y mantener relaciones de los menores $y$ adolescentes, incluso mediante tecnologías de la información y la comunicación".

12 Sentencia de la Audiencia Provincial de Ciudad Real, SAP CR 360/2019, de 14/03/2019, nº de Resolución 9/2019, Ponente: Mónica Céspedes Cano: “... el tipo penal del abuso sexual se configura en nuestro ordenamiento enmarcado en los siguientes requisitos: de una parte, un elemento objetivo de contacto corporal, tocamiento impúdico, o cualquier otra exteriorización o materialización con significación sexual. Este elemento objetivo, de contacto corporal, puede ser ejecutado directamente por el sujeto activo sobre el cuerpo del sujeto pasivo o puede ser ordenado por el primero para que el sujeto pasivo lo realice sobre su propio cuerpo siempre que el mismo sea impuesto. De otra parte, el subjetivo o tendencial que se incorpora a la sentencia con la expresión del ánimo,o propósito de obtener una satisfacción sexual a costa de otro." 
Sin embargo, es el propio TS, el que, con ánimo de precisar este término, afirma que: "esta Sala se ha pronunciado también en reiteradas ocasiones indicando que en el delito de abuso sexual el ánimo libidinoso, aunque es normal que concurra, no es un requisito del tipo y, por tanto, su inexistencia no determina la ausencia de tipicidad de la conducta". Alegando para ello, la necesidad de que concurra en el sujeto activo el elemento subjetivo de dolo, es decir, cuando tiene conciencia y voluntad de la realización del tipo ${ }^{13}$.

\subsection{Debate Doctrinal: la indemnidad sexual}

Como hemos aludido anteriormente, establecer el bien jurídico no ha estado exento de controversias y mucho menos a la hora de delimitarlo en el ámbito objeto de este trabajo. Un breve análisis en cuanto a su evolución legal y doctrinal pasa por determinar que hasta la reforma de 1989, la "honestidad" se concretaba como el bien jurídico protegido hasta ese momento, hecho que devino, para la mayoría de la doctrina, como un término ambiguo y de carácter moralizante que debía sustituirse por "moral sexual", entendida como aquella que se integraba en el orden moral sexual vigente en la sociedad del momento, posición que, desde el punto de vista del Derecho Penal, podía atentar contra la seguridad jurídica y suponer la pérdida del carácter democrático y plural de un Estado de Derecho.

Analizados estos obstáculos, es con la reforma por LO 3/1989, de 21 de junio, de actualización del Código Penal, cuando se produce un cambio fundamental en el bien jurídico protegido, sustituyéndose el epígrafe de "Delitos contra la honestidad" por "Delitos contra la libertad sexual”, estableciéndose ésta como el bien jurídico protegido, ello en el sentido de entender la libertad sexual como una manifestación de la libertad personal, así se manifiestan autores como Monge Fernández, la cual entiende que se trata de "la libertad de la persona para decidir libremente sobre el lugar, tiempo, modo y pareja de la relación sexual; entendida como el derecho de la persona a disponer sobre el momento, forma, medida y significado de su libre comportamiento sexual; en ello, se incluye la libertad de elección de la pareja. Es la autodeterminación personal en el marco de las relaciones sexuales, como una faceta más de la capacidad de obrar. Significa que el titular de la misma resuelve su comportamiento sexual conforme a motivos propios en el sentido de que es él quien decide sobre su sexualidad, sobre cómo, cuándo y con quién mantiene relaciones sexuales $" 14$.

13 Vid. Sentencia del Tribunal Supremo, Sala de lo Penal, de 23/07/2019, $n^{\circ}$ de Resolución 378/2019, Ponente: Eduardo de Porres Ortiz de Urbina: "Sirva de ejemplo la STS 897/2014, de 15 de diciembre, con cita de otra anterior número 494/2007, de 8 de junio, en la que se afirmaba que "(...) el tipo subjetivo exige el conocimiento de la naturaleza sexual del acto que se ejecuta, lo que implica, a su vez, la conciencia de afectación del bien jurídico. Tradicionalmente se ha requerido la concurrencia de un ánimo tendencial consistente en el llamado ánimo libidinoso o propósito de obtener una satisfacción sexual. Generalmente, tal ánimo concurrirá en la conducta del sujeto, pues es precisamente la que lo explica. Sin embargo, no puede descartarse la posibilidad de ejecución de actos que por su propia naturaleza o contenido son claramente atentatorios a la libertad o indemnidad sexual de la víctima, en los que, sin embargo, el propósito del autor sea diferente al antes referido. En estos casos, la conducta objetiva es suficiente para entender cumplidas las exigencias del tipo, pues sin duda se afecta a la libertad sexual de la víctima. Desde el aspecto subjetivo, para afirmar el dolo basta con el conocimiento del peligro creado con la acción, de manera que sea suficiente que el autor conozca que su conducta, por su propia naturaleza, puede afectar negativamente a la libertad o indemnidad sexual de la víctima (...)”.

14 MONGE FERNÁNDEZ, A.: “De los abusos y las agresiones sexuales a menores de trece años .Análisis de los artículos 183 y 183 bis CP, conforme a la LO 5/2010”. Ed. J.M. Bosch. Barcelona, 2011. p. 53. 
Ante todo ello, surgen, sin embargo, opiniones que critican la libertad sexual como bien jurídico protegido en el ámbito de menores e incapaces, ya que si ésta es la capacidad para auto determinarse en el ámbito sexual, no se puede proteger aquello de lo que estos individuos carecen. Es en estos casos donde el legislador penal, atiende dichas manifestaciones y a partir de la LO 11/1999, de 30 de Abril, de modificación del Título VIII del Libro II del Código Penal, aprobado por Ley Orgánica 10/1995, de 23 de noviembre, añade como nueva rúbrica de este Título: "Delitos contra la libertad e indemnidad sexuales".

Visto lo anterior, se plantea un debate doctrinal en torno a proteger y delimitar la futura capacidad de autodeterminación sexual del menor en beneficio de su propio interés. Un sector mayoritario defiende "indemnidad sexual" en estos casos, como el potencial desarrollo de la capacidad de autodeterminación sexual. Un sector minoritario, entre los que se encuentran: Orts Berenguer, Suarez-Mira y Díez Ripollés, entre otros, critican la tesis de la indemnidad sexual como bien jurídico protegido ya que en determinados casos el consentimiento de los menores o incapaces adquiere cierta relevancia.

Concretamente, el Profesor Díez Ripollés se posiciona en contra de la teoría de la "indemnidad sexual" y entiende innecesaria la introducción de tal bien jurídico en el CP, considerando incongruente el hecho de que el legislador, por un lado, en las agresiones sexuales, dé cierta trascendencia al consentimiento de los menores porque concurre violencia e intimidación y, por tanto, la presunción de no ser consentidas, mientras que en el caso de los abusos sexuales se parta de la base de que el consentimiento prestado por éstos es ineficaz. Con ello, concluye que los menores e incapaces ostentarían capacidad para determinarse en un plano sexual y por tanto poseerían libertad sexual, aunque originalmente, por sus especiales características, se considerase inválido su consentimiento. Ahondando en esta posición, considera, como poco, absurdo, el hecho de que se dé igualmente validez al consentimiento prestado por menores e incapaces cuando estos mantienen relaciones sexuales con otros menores. Como argumento final, tacha de impreciso y vago el término "indemnidad sexual", aludiendo a una posible vulneración de los principios de certeza y seguridad jurídica ${ }^{15}$.

Desde otro punto de vista, y siguiendo a autores como Cerezo Mir y Muñoz Conde, que critican esta posición minoritaria, la profesora Antonia Monge Fernández manifiesta que desde la anterior se parte de premisas erróneas e insostenibles, ya que si se niega la validez del consentimiento de los menores para mantener una relación sexual, considerándola abuso, cuanto más devendrá ineficaz el consentimiento obtenido por medio de violencia e intimidación en las agresiones sexuales, dato que avala en numerosas ocasiones la propia jurisprudencia. Por otro lado, señala la imprecisión que manifiestan otros intereses protegidos por el derecho penal con carácter de bien jurídico: integridad moral u honor. Además, como punto discordante, puede reconocer a los incapaces una determinada capacidad para disponer libremente pero es contundente a la hora de negarla

Esta autora hace esta afirmación con cita de BORJA JIMENEZ, E.: “Curso de politica criminal”. Ed. Tirant lo Blanch. Valencia 2003, p. 156.

15 MONGE FERNÁNDEZ, A.: "De los abusos y las agresiones sexuales a menores de trece años .Análisis de los artículos 183 y 183 bis CP, conforme a la LO 5/2010". Ed. J.M. Bosch. Barcelona, 2011. ps. 68 Y 69. 
respecto a cualquier vulneración de la sexualidad en un recién nacido, ya que este carece de toda capacidad natural de autodeterminación sexual y de consentimiento ${ }^{16}$.

En definitiva, y tras el debate suscitado, a nuestro entender, podríamos estar hablando de la existencia de una premisa mayor, cual es la "libertad sexual", donde se incluiría como premisa menor la "indemnidad sexual". Es cierto que el bien/es jurídico protegido en una determinada acción o delito pudieran ser varios: libertad, integridad, dignidad e incluso vida. Por ello, entendemos que, quizá, haya que ceñirse al supuesto concreto que evaluamos en un determinado momento, estableciendo qué interés o intereses protege el Derecho. Nuestro posicionamiento sobre este debate, cabría entenderlo como más práctico que teórico, en el sentido de individualizar el bien/es jurídico caso a caso. Por lo tanto es posible la coincidencia en un supuesto determinado de varios bienes, desde la libertad, indemnidad e incluso la propia dignidad.

\section{DIFERENCIA ESENCIAL ENTRE ABUSO, AGRESIÓN Y ACOSO SEXUAL: TIPOS DELICTIVOS CONCERNIENTES A MENORES}

Diferenciar las conductas de abuso y agresión es tan simple como requerir la necesidad de la concurrencia de un elemento fundamental como es la presencia de violencia o intimidación, elemento que concurre en el caso de la agresión, no así en el supuesto de abuso. Mientras que la ausencia de violencia o intimidación supone el elemento diferenciador, coinciden en el hecho de que se trata de un ataque a la libertad sexual no consentido o contra la indemnidad sexual de menores o personas con discapacidad necesitadas de especial protección ${ }^{17}$. Ello no puede llevarnos a pensar que en una agresión sexual se protege la libertad sexual y en los abusos, la indemnidad sexual, confusión que nos aclara el art. 183 del CP en sus apartados 1 y $2^{18}$.

El acoso, sin embargo, va a provocar que la víctima se sienta amenazada dentro de una específica relación laboral, docente o de prestación de servicios, se trata de un atentado contra su integridad moral o una injuria grave mediante la solicitud de favores de naturaleza sexual para sí o para un tercero.

\subsection{Referencia al concepto "violencia e intimidación" como elementos diferenciadores del tipo}

Expresadas estas diferencias, es importante delimitar el concepto de "violencia e intimidación" a la hora de determinar el tipo delictivo.

En este sentido, es la Jurisprudencia de los tribunales la que va a acotar los términos, concretamente el Tribunal Supremo (en adelante TS) establece que "la violencia o

16 MONGE FERNÁNDEZ, A.: "De los abusos y las agresiones sexuales a menores de trece años .Análisis de los artículos 183 y 183 bis CP, conforme a la LO 5/2010". Ed. J.M. Bosch. Barcelona, 2011. ps. 72 a 75.

«1. El que realizare actos de carácter sexual con un menor de dieciséis años, será castigado como responsable de abuso sexual a un menor con la pena de prisión de dos a seis años.

2. Cuando los hechos se cometan empleando violencia o intimidación, el responsable será castigado por el delito de agresión sexual a un menor con la pena de cinco a diez años de prisión...". 
intimidación empleadas en los delitos de agresión sexual no han de ser de tal grado que presenten caracteres irresistibles, invencibles o de gravedad inusitada, sino que basta que sean suficientes y eficaces en la ocasión concreta para alcanzar el fin propuesto, paralizando o inhibiendo la voluntad de resistencia de la víctima y actuando en adecuada relación causal, tanto por vencimiento material como por convencimiento de la inutilidad de prolongar una oposición de la que, sobre no conducir a resultado positivo, podrían derivarse mayores males, de tal forma que la calificación jurídica de los actos enjuiciados debe hacerse en atención a la conducta del sujeto activo. Si éste ejerce una intimidación clara y suficiente, entonces la resistencia de la víctima es innecesaria pues lo que determina el tipo es la actividad o la actitud de aquél, no la de ésta (STS 609/2013, de 10 de julio de 2013). Pero también ha señalado la doctrina de esta Sala, (SSTS 381/97, de 25 de marzo, 190/1998, de 16 de febrero y 774/2004, de 9 de febrero, entre otras), que la intimidación, a los efectos de la integración del tipo de agresión sexual, debe ser seria, previa, inmediata, grave y determinante del consentimiento forzado"19.

En este caso, ha entendido que el concepto de violencia se refiere al empleo de fuerza física: "Y en la Sentencia 449/2000, de 4 de septiembre se declara que esta Sala ha perfilado los elementos integrantes de la violencia, en sentencias de 18 de octubre de 1993, 28 de abril y 21 de mayo de 1998, y en la sentencia 1145/98 de 7 de octubre, estimando que equivale a acometimiento, coacción o imposición material, e implica una agresión real más o menos violenta, o por medio de golpes, empujones, desgarros, es decir, fuerza eficaz y suficiente para vencer la voluntad de la víctima". ${ }^{20}$

Mientras que, este mismo órgano judicial es el que determina que: "La intimidación consiste en la amenaza de un mal grave, futuro y verosímil, si la víctima no accede a participar en una determinada acción sexual, pero no alcanza ordinariamente a supuestos en que simplemente se reclama discreción sobre los hechos realizados". Llegando a matizar que: "La transformación en agresión sexual exige la concurrencia adicional de fuerza o intimidación en sentido propio, pues constituiría una duplicidad punitiva valorar repetidamente la minoría de edad como determinante absoluta de la tipicidad de las acciones sexuales realizadas, y adicionalmente como elemento que califica de violento o intimidativo un comportamiento que en sí mismo no reviste dicha caracterización" 21.

La Jurisprudencia aclara que no es necesario sólo la presencia de vis física o el empleo de armas para que se aprecie un componente intimidatorio, sino que la coacción psíquica o el miedo también llevan a apreciar la concurrencia de intimidación en dichas conductas. Intimidación que, sobre todo en el ámbito familiar, no tiene por qué ser inmediata al acto de agresión, sino que puede ser continua y persistente en el tiempo ${ }^{22}$.

19 Vid. Sentencia del Tribunal Supremo, Sala de lo Penal, de 30/06/2014, $\mathrm{n}^{\mathrm{o}}$ de Resolución 553/2014, Ponente: Cándido Conde-Pumpido Touron.

20 Vid. Sentencia del Tribunal Supremo, Sala de lo Penal, de 23/09/2002, no de Resolución 1546/2002, Ponente: Carlos Granados Pérez.

21 Vid. Sentencia del Tribunal Supremo, Sala de lo Penal, de 28/05/2015, no de Resolución 355/2015, Ponente: Cándido Conde-Pumpido Touron.

22 Vid. Sentencia del Tribunal Supremo, Sala de lo Penal, de 22/12/2008, nº de Resolución 914/2008, Ponente: Diego Antonio Ramos Gancedo: "La valoración jurídica de los hechos declarados probados que hace la sentencia respecto al componente intimidatorio, no admite tacha ni réplica, pues, en efecto, se da la "concurrencia de intimidación en relación de medio a fin, para conseguir vencer la natural oposición de la víctima al mantenimiento de relaciones sexuales con su progenitor; intimidación que, conforme ha manifestado el TS en Auto de 10 de 
De igual forma precisa que la amenaza, aunque normalmente va dirigida a la víctima, también puede recaer sobre un tercero afín a la misma: "Las constantes amenazas que profería el acusado referidas siempre a la madre biológica de las menores o a ellas mismas, y consistentes en amenazas de muerte o con devolverlas a su país de origen (Sierra Leona)..." "23.

Es posible entender que violencia e intimidación puedan ir aparejadas ya que una violencia constante y reiterada puede provocar en la víctima un miedo que le impida resistirse a nuevas agresiones.

Recientes Sentencias del TS concretan, en determinados casos, la diferencia entre dichos términos: "Recordemos que, históricamente, en Roma el derecho pretoriano atribuía a la violencia fisica o moral una significación un tanto distinta. La primera -vis absoluta-resultaba del empleo de una fuerza material que reducía a la víctima a un estado pasivo, convertida en mero instrumento de la voluntad de otro; destruía la voluntad, y por tanto el acto obrado carecía de existencia como acto jurídico. Es lo que en la actualidad se ha entendido que es la violencia. Sin embargo, la violencia moral -vis compulsi$v a$ - en cambio, consistía en el temor actual de un mal inminente: debilita la voluntad sin destruirla. El acto no era inexistente, pero como la voluntad estaba viciada, se reconocía al sujeto el derecho a pedir la rescisión, independientemente, y además de su derecho a reclamar por la acción civil de daños y perjuicios. Se decía con una frase de los glosadores romanos que explicaba la doctrina: del acto; pero si eligió consintió aunque imperfectamente. Luego, el contrato existía, aunque es susceptible de anulación por el empleo de la vis compulsiva. En este último caso es lo que ahora se entiende y recoge en el texto penal como intimidación. Así, para que se entienda cometida la conducta integrante del tipo penal del art. 178 CP se exige una conducta violenta de contenido material, como vis física, o intimidación, como vis compulsiva, ejercida sobre el sujeto pasivo, ya sea de modo directo o de modo indirecto". ${ }^{24}$

marzo de 2.005, consiste en "una coacción moral que se proyecta sobre la capacidad de decisión de la víctima, cuya voluntad se doblega acomodándola a los deseos de quien la ejerce mediante la amenaza injusta e ilícita de un mal grave e inminente, de suerte que la conducta de la víctima se realiza no por el ejercicio libre de su voluntad, sino por la coerción psicológica que soporta, que genera una inquietud anímica apremiante y una aprensión racional o recelo más o menos justificado. En este sentido viene declarando la jurisprudencia de esta Sala que la intimidación no puede limitarse al empleo de medios físicos o uso de armas, siendo suficiente las palabras o actitudes conminatorias o amenazantes cuando, por las circunstancias coexistentes (ausencia de terceros, superioridad física del agente, credibilidad de los males anunciados expresa o implícitamente, etc.) haya que reconocerles idoneidad para la consecución del efecto inhibitorio pretendido (SSTS de 24 de enero de 1989, 9 de octubre EDJ 1990/9129 y 21 de diciembre de 1990 EDJ 1990/1184, entre otras)... La intimidación de la víctima de una agresión puede y suele realizarse inmediatamente antes de ejecutarse el atentado contra la libertad sexual, como medio para conseguir que aquélla desista de su voluntad contraria a la relación sexual. Pero la intimidación también puede ser generada -sobre todo en el ámbito familiar-mediante una paulatina y persistente coerción y amedrentamiento del sujeto pasivo que va minando progresivamente su capacidad de decidir libremente sobre la conducta sexual que se le requiere, hasta someterla a una sumisión absoluta, con nula capacidad de oponerse ante los males con que reiteradamente se le amenaza de no acceder a los deseos del sujeto activo. Es lo que se denomina un estado de intimidación permanente o una situación objetiva intimidante, susceptible de integrar el elemento intimidatorio que precisa el tipo penal de agresión sexual y que, en el caso actual, a tenor de la actuación del acusado que se describe en el "factum", y de las circunstancias concurrentes, es indudable."

23 Vid. Sentencia del Tribunal Supremo, Sala de lo Penal, de 22/12/2008, nº de Resolución 914/2008, Ponente: Diego Antonio Ramos Gancedo.

24 Vid. Sentencia del Tribunal Supremo, Sala de lo Penal, de 17/01/2019, $n^{\circ}$ de Resolución 13/2019, Ponente: Vicente Magro Servet. Sentencia que añade una clara distinción entre abusos y agresiones sexuales: " $Y$ asi la clave diferencial entre el delito de agresión sexual y el de abuso sexual queda verificada por la concurrencia, o 
Es la Sentencia del TS de 30 de mayo de 2019, la que precisa el concepto de intimidación, concretamente en su Fundamento de Derecho Séptimo, haciendo un relato jurisprudencial en el tiempo de su acepción, diferenciando conceptos como intimidación y prevalimiento, así: "Es cierto que la línea divisoria entre la intimidación y el prevalimiento puede ser difícilmente perceptible en los casos límite como lo es la diferencia entre un consentimiento cercenado por la amenaza de un mal y el viciado que responde al tipo del abuso, donde la víctima en alguna medida también se siente intimidada. Sin embargo, este elemento debe tener relevancia objetiva y asi debe constatarse en el hecho probado. Lo relevante es el contenido de la acción intimidatoria llevada a cabo por el sujeto activo más que la reacción de la víctima frente a aquélla”. Llegando incluso a determinar que el miedo que pueda sentir una víctima no convierte en intimidatoria una acción, debiendo analizarse detenidamente las circunstancias que rodean al caso concreto ${ }^{25}$.

\subsection{Tipos delictivos concernientes a menores: abuso y agresión sexual}

Una vez expuesta la diferencia entre estos delitos vamos a centrarnos en delimitar los tipos que expresamente recoge nuestro Código Penal, en su título VIII.

Como ya hemos manifestado, la edad de consentimiento sexual se eleva a los dieciséis años, siendo la propia Directiva 2001/93/UE la que define dicho concepto como "la edad por debajo de la cual, de conformidad con el Derecho nacional, está prohibido realizar actos de carácter sexual con un menor" ${ }^{\prime 26}$, con el fin de mejorar la protección de

no, de violencia o intimidación: Así: Art. 178 CP (agresión sexual). Empleo de violencia o intimidación en ataque a la libertad sexual de una persona. Art. 181 CP (abuso sexual). Ataque a la libertad sexual de una persona sin violencia o intimidación. En ambos casos, evidentemente, no hay consentimiento. La violencia es un acto claro de empleo de la misma sobre el cuerpo de la víctima, no exigiéndose un acto causante de una lesión, sino el empleo coercitivo, utilizando un movimiento sobre una parte del cuerpo de la víctima por el que intente vencer su voluntad, como puede ser cogerle de las manos de forma fuerte para vencer su resistencia a llevar a cabo el acto sexual, o ponerse encima de la víctima tras haberla arrojado al suelo. No se exige un resultado lesivo con el empleo de la violencia, sino su mero uso sobre alguna parte del cuerpo de la víctima para someterla y vencer su oposición, por lo que valdría cogerle de las muñecas, o brazo de forma fuerte para que no se pueda mover, o escapar y atacar a su libertad sexual. Mientras tanto, en el abuso sexual no hay "ningún empleo de violencia o intimidación. De ahí que esta Sala del Tribunal Supremo haya señalado en sentencias 396/2018 de 26 Jul. 2018, Rec. 2194/2017 y 615/2018 de 3 Dic. 2018, Rec. 778/2018 que Cualquier acción que implique un contacto corporal inconsentido con significación sexual, en la que concurra el ánimo tendencial ya aludido, implica un ataque a la libertad sexual de la persona que lo sufre y, como tal, ha de ser constitutivo de un delito de abuso sexual previsto y penado en el artículo $181 \mathrm{CP}$; sin perjuicio de que la mayor o menor gravedad de dicha acción tenga reflejo en la individualización de la pena".

25 Vid. Sentencia del Tribunal Supremo, Sala de lo Penal, de 30/05/2019, no de Resolución 282/2019, Ponente: Vicente Magro Servet: "El miedo es una condición subjetiva que no puede transformar en intimidatoria una acción que en sí misma no tiene ese alcance objetivamente. La S.T.S. 1259/04 expone que la intimidación es de naturaleza psíquica y requiere el empleo de cualquier fuerza de coacción, amenaza o amedrentamiento con un mal racional y fundado (STS núm. 1583/2002, de 3 octubre). En ambos casos han de ser idóneas para evitar que la víctima actúe según las pautas derivadas del ejercicio de su derecho de autodeterminación, idoneidad que dependerá del caso concreto, pues no basta examinar las características de la conducta del acusado sino que es necesario relacionarlas con las circunstancias de todo tipo que rodean su acción".

26 Vid. Artículo 2 b) Directiva 2011/92/UE del Parlamento Europeo y del Consejo de 13 de diciembre de 2011 relativa a la lucha contra los abusos sexuales y la explotación sexual de los menores y la pornografía infantil y por la que se sustituye la Decisión marco 2004/68/JAI del Consejo. Concepto tratado y desarrollado concretamente en Pérez Vallejo, A.M./Pérez Ferrer, F.: Bullying, ciberbullying y acoso con elementos sexuales, Dykinson, Madrid, 2016. 
los menores dentro de nuestra legislación, hecho fundamental a la hora de tener en cuenta el tipo delictivo a aplicar ${ }^{27}$.

Con ello es indiscutible que en nuestro estudio, el sujeto pasivo será un menor de 16 años, tanto hombre como mujer, mientras que el sujeto activo será necesariamente un mayor de 18 años, que incluirá, del mismo modo, al hombre y a la mujer.

El artículo 178 del CP regula el tipo básico referente a las "agresiones sexuales", recogiendo como agravados el artículo 179 como delito de violación e incluyendo en el art. 180 otras conductas cualificadas, a su vez que en el artículo 181del CP se recoge el tipo básico "De los abusos sexuales", todos ellos comprendidos en los Capítulos I y II, mientras que el Capítulo II bis del CP trata, concretamente, "De los abusos y agresiones sexuales a menores de dieciséis años". Con esta manifestación pretendemos constatar que pese a que pueda parecer que se está diferenciando entre distintos tipos según el sujeto pasivo, no se puede entender que los conceptos del tipo básico referidos en los Capítulos I y II sean distintos a los del Capítulo II bis.

Es oportuno hacer referencia, a que los menores comprendidos entre los 16 y 17 años, gozan, como no puede ser de otra forma, de protección penal, si bien limitada a los supuestos de engaño o abuso de posición reconocida de confianza, autoridad o influencia (art. $182 \mathrm{CP}$ ), actos de exhibicionismo o provocación sexual (arts. 185 y 186, que se refieren a "menores de edad" sin efectuar distinción), y delitos relativos a la prostitución y corrupción de menores (arts. 188 y 189 CP).

\section{1.a. Tipo básico: abuso y agresión sexual}

La regulación actual sobre los delitos de abusos y agresiones a menores de 16 años prevé su tipo básico en el artículo 183.1 del CP, referido a abusos, mientras que en el $183.2 \mathrm{se}$ refiere a las agresiones sexuales, añadiendo como novedad "cuando con violencia o intimidación compeliere a un menor de dieciséis años a participar en actos de naturaleza

27 La Exposición de Motivos de la Ley Orgánica 1/2015, de 30 de marzo, por la que se modifica la Ley Orgánica 10/1995, de 23 de noviembre, del Código Penal, establece "Como novedad más importante, se eleva la edad del consentimiento sexual a los dieciséis años. La Directiva define la «edad de consentimiento sexual» como la «edad por debajo de la cual, de conformidad con el Derecho Nacional, está prohibido realizar actos de carácter sexual con un menor.» En la actualidad, la edad prevista en el Código Penal era de trece años, y resultaba muy inferior a la de los restantes países europeos -donde la edad mínima se sitúa en torno a los quince o dieciséis años-y una de las más bajas del mundo. Por ello, el Comité de la Organización de las Naciones Unidas sobre Derechos del Niño sugirió una reforma del Código penal español para elevar la edad del consentimiento sexual, adecuándose a las disposiciones de la Convención sobre los Derechos de la Infancia, y así mejorar la protección que España ofrece a los menores, sobre todo en la lucha contra la prostitución infantil.

De esta manera, la realización de actos de carácter sexual con menores de dieciséis años será considerada, en todo caso, como un hecho delictivo, salvo que se trate de relaciones consentidas con una persona próxima al menor por edad y grado de desarrollo o madurez. Y se establecen agravaciones si, además, concurre violencia o intimidación, o si los abusos consisten en acceso carnal por vía vaginal, anal o bucal, o introducción de miembros corporales u objetos por alguna de las dos primeras vías. En el caso de los menores de edad -de menos de dieciocho añospero mayores de dieciséis años, constituirá abuso sexual la realización de actos sexuales interviniendo engaño o abusando de una posición reconocida de confianza, autoridad o influencia sobre la víctima.

Por otra parte, se tipifica expresamente la conducta de hacer presenciar a un menor de dieciséis años actos o abusos sexuales sobre otras personas y se prevé la imposición, en estos casos, de penas de hasta tres años de prisión.

En los delitos contra la prostitución, se establece una separación más nítida entre los comportamientos cuya víctima es una persona adulta, de aquellos otros que afectan a menores de edad o a personas con discapacidad necesitadas de especial protección. En este segundo caso, se elevan las penas previstas con el fin de armonizar las legislaciones europeas, y se introducen nuevas agravantes para combatir los supuestos más lesivos de prostitución infantil". 
sexual con un tercero o a realizarlos sobre sí mismo" 28 . Con ello, se amplía el ámbito objetivo del delito, en su afán de proteger el interés superior del menor.

Ese interés de proteger al menor hace que, en recientes Sentencias del TS, se especifique si dentro del tipo de agresión o abuso sexual se abarcan actos más allá del "contacto sexual" que pueda parecer exigirse para que exista un atentado contra la libertad sexual, concluyendo este Tribunal que no es exigible para que se consume el delito, no sólo en ámbitos tecnológicos, sino incluso, en ámbitos de proximidad física. Ello, porque ese "contacto sexual" no sólo ha de referirse a actos en los que intervengan órganos genitales, en los que quedaría clara su condición, sino a otro tipo de actos, como tocamientos o besos, en los que hemos de decantarnos por tener en cuenta la gravedad de los mismos, su trascendencia y el contexto en el que se produce ${ }^{29}$.

En relación con lo anterior, vuelve a ser el Tribunal Supremo, en su labor interpretativa de la ley, el que delimite conceptos referidos a determinar qué se entiende por actos de carácter sexual, para ello en su Sentencia de 12.05.2019, establece que: "En ocasiones se producen situaciones en las que la ambigüedad de una cierta acción es susceptible de inducir dudas acerca de su carácter. Pero no ocurre así en este caso en el que la connotación sexual del comportamiento analizado es inequívoca. En estos supuestos en los que el comportamiento es menos invasivo para la indemnidad sexual, como pudiera ser este último caso, en atención a que los tocamientos se hicieron sobre la ropa, y se trató de un solo beso, el ánimo libidinoso del acusado que el factum describe, opera como elemento determinante del delito, que así prevalece frente a calificaciones más leves (en este sentido, SSTS 928/1999 de 4 de junio; 87/2011 de 11 de febrero; 55/2012 de 7 de febrero o STS 702/2013 de 1 de octubre) "'30.

28 Vid. Artículo 183.2 in fine del Código Penal.

29 Vid. Sentencia del Tribunal Supremo, Sala de lo Penal, de 12/04/2016, no de Resolución 301/2016, Ponente: Manuel Marchena Gómez: "Son muchos los precedentes de esta Sala en los que la aplicación del art. 183 del $C P$ no se ha visto obstaculizada por el hecho de que no mediara contacto físico entre agresor y víctima. Y no sólo en aquellos casos en los que la ausencia de relación física está ligada al escenario telemático en el que se desarrolla el abuso. Así, por ejemplo, en la STS 1397/2009, 29 de diciembre, decíamos que "... el delito de agresión sexual del art. 178 se consuma atentando contra la libertad sexual de otra persona sin que se exija que el sujeto necesariamente toque o manosee a su víctima. (...). Que la satisfacción sexual la obtenga (el acusado) tocando el cuerpo de la víctima o contemplándola desnuda mientras se masturba es indiferente para integrar para ello lo que es en ambos casos un comportamiento de indudable contenido sexual. Pero más allá de aquellos supuestos en los que la falta de contacto físico se produce en un contexto de proximidad entre agresor y víctima, las nuevas formas de comunicación introducen inéditos modelos de interrelación en los que la distancia geográfica deja paso a una cercanía virtual en la que la afectación del bien jurídico, no es que sea posible, sino que puede llegar a desarrollarse con un realismo hasta ahora inimaginable. El intercambio de imágenes de claro contenido sexual, obligando a un menor a enviar fotografias que atentaban contra su indemnidad sexual (ATS 1474/2014, 18 de septiembre), la obtención de grabaciones con inequivocos actos sexuales ejecutados por menores de edad ( STS 864/2015, 10 de diciembre ), la introducción anal y vaginal de objetos por parte de dos niñas, inducidas por su propia madre para su observación por un tercero a través de Internet ( STS 786/2015, 4 de diciembre ), son sólo algunos ejemplos bien recientes de resoluciones de esta Sala en las que hemos considerado que el ataque a la indemnidad sexual del menor de edad puede producirse sin esa contigüidad física que, hasta hace pocos años, era presupuesto indispensable para la tipicidad de conductas de agresiones o abusos sexuales a menores".

30 Vid. Sentencia del Tribunal Supremo, Sala de lo Penal, de 12/05/2012, no de Resolución 126/2015, Ponente: Ana María Ferrer García: "Por lo pronto este relato hace referencia a dos de los elementos que exige el artículo 181 del $C P$, que se atente contra la libertad e indemnidad sexuales de la víctima. Los tocamientos que se describen tienen un inequívoco contenido sexual y por su propia naturaleza, son idóneos para comprometer aquéllas. Además se concreta que respondieron al ánimo libidinoso del acusado, es decir, a un propósito por su parte de obtener satisfacción sexual a costa de otro, en este caso su sobrina menor de edad, cuya indemnidad sexual resultó comprometida". 


\section{1.b. Tipos agravados. Análisis Jurisprudencial: “acceso carnal”}

Una vez expuestos los tipos básicos de abuso y agresión sexual contemplados en los artículos 183.1 y 2 respectivamente del CP, el artículo 183.3 recoge los tipos agravados de estas conductas: "Cuando el ataque consista en acceso carnal por vía vaginal, anal o bucal, o introducción de miembros corporales u objetos por alguna de las dos primeras vías, el responsable será castigado con la pena de prisión de ocho a doce años, en el caso del apartado 1, y con la pena de doce a quince años, en el caso del apartado 2". Haciendo referencia este artículo en su segundo apartado, art. 183.3 in fine, al supuesto de violación, aunque obviando su denominación como tal, a diferencia de lo establecido en el art. 179 del CP.

En este artículo, la polémica, tanto doctrinal como jurisprudencial, se centra en la delimitación del concepto "acceso carnal", y en este caso, trataremos su evolución a través de las Sentencias del Tribunal Supremo.

En este sentido, destacar el análisis detallado que se establece por Sentencia del TS de 13/12/2006, en la cual se explica la evolución sufrida con respecto a este concepto, así: "Ahora bien el legislador, a partir de la reforma de la LO. 11/99 suprimió esa distinción para referirse ahora a "acceso carnal por vía vaginal, anal o bucal”, lo que permite ya defender la interpretación que ese acceso carnal supone la introducción del órgano sexual masculino que puede realizarse en las cavidades que el tipo penal señala, vaginal, anal o bucal, rellenándose la tipicidad tanto cuando el sujeto activo realiza la conducta, esto es, cuando introduce el pene, en este caso, en la boca del menor, como cuando es la víctima la que es obligada a realizar la conducta contra su voluntad con violencia o intimidación (agresión sexual) o sin su consentimiento o con su consentimiento viciado (abuso sexual), introduciendo su órgano sexual en alguna de las cavidades típicas del sujeto activo. Tal interpretación venía permitida por el texto del precepto desde 1999, por lo tanto, con anterioridad a los hechos enjuiciados, de forma que no se ha acudido a la analogía in malam parten, prohibida en el ámbito del Derecho Penal"'31.

31 Vid. Sentencia del Tribunal Supremo, Sala de lo Penal, de 13/12/2006, nº de Resolución 1295/2006, Ponente: Miguel Colmenero Menéndez de Luarca: "El artículo 179 incrementa la pena prevista en el artículo 178 para las agresiones sexuales (con violencia o intimidación), cuando la agresión "consista en acceso carnal por vía vaginal, anal o bucal". El acceso carnal se ha identificado originariamente con la cópula, esto es, con la introducción del miembro viril en la cavidad vaginal. Hasta la reforma de 1989, el Código Penal derogado consideraba la violación como el acto de yacer con una mujer una vez excluido su consentimiento, en alguna de las formas típicas (menor de 12 años, privada de razón o de sentido y con violencia o intimidación). En la referida reforma, el concepto penal del acceso carnal se amplió, al definir el delito de violación como el cometido por aquel que "tuviere acceso carnal con otra persona, sea por vía vaginal, anal o bucal", sancionando así algunas conductas en las que el sujeto pasivo podía ser un varón, si bien permanecía la exigencia implícita de que lo introducido debería ser en todo caso el miembro viril para que la conducta pudiera ser considerada como acceso carnal. El Código Penal vigente, en su redacción originaria, sin utilizar la palabra "violación", agravaba las agresiones sexuales del artículo 178 (atentados a la libertad sexual con violencia o intimidación), cuando consistieran en "acceso carnal, introducción de objetos o penetración bucal o anal", con lo que volvía al concepto inicial de acceso carnal al distinguir entre éste y otras penetraciones, también referidas al miembro viril, pero efectuadas por otras vías distintas de la vaginal. La reforma efectuada por la Ley Orgánica 11/1999 volvió a la situación anterior, pues nuevamente redacta la conducta agravada estableciendo que se apreciará cuando la agresión sexual consista en acceso carnal por vía vaginal, anal o bucal, equiparando a esta conducta la introducción de objetos por las dos primeras vías. Finalmente, la redacción actual procede de la reforma operada por la Ley Orgánica 15/2003, que mantiene la redacción anterior, si bien introduce nuevamente el vocablo "violación" $y$ añade como conducta equiparada la introducción de miembros corporales por cualquiera de las dos primeras vías. Por lo tanto, el concepto penal de acceso carnal en la actualidad comprende no solo la cópula, como introducción del miembro viril en la vagina, sino también la introducción de aquél en las cavidades anal o bucal. 
Es en esta Sentencia donde, a través de un voto particular, se discutía la posible vulneración del principio de legalidad por conllevar "una extensión analógica en perjuicio del acusado que no es admisible por el derecho penal", ofreciendo argumentos que apoyarían una tesis contraria: "La decisión adoptada, por mayoría en el Pleno no jurisdiccional de 25 de Mayo de 2005, llega a la conclusión, de que hacerse penetrar analmente por un menor de edad, constituye una modalidad de acceso carnal (...) En definitiva, la penetración no la realiza el delincuente sexual, sino que disfruta de la misma a costa de la influencia sobre un menor. Esta situación presenta caracteres dificilmente admisibles por la teoría de la acción (...) Las conductas o acciones solo se pueden incriminar si se realizan en la forma que contempla el legislador, sin que puedan ampliarse a otras acciones o comportamientos completamente distintos en cuanto los componentes de la acción. Si admitimos que es igual la penetración sexual que hacerse penetrar podríamos ampliar esta conducta inversa a una serie de figuras penales con resultados absolutamente incongruentes: hacerse robar, hacerse estafar, hacerse lesionar, hacerse matar, que tiene, como es lógico, una modalidad delictiva absolutamente distinta y así, llevados de esta interpretación, crear un Código paralelo de conductas invertidas en las que el sujeto pasivo pasa a ser sujeto activo (...)Nos encontramos ante una conducta básica del artículo 178 del Código Penal en cuanto que se ha atentado contra la libertad sexual de una persona utilizando fuerza o intimidación”.

De dicha polémica también se hace eco la Sentencia del TS de 06 de julio de 2018, en la que reproduce y hace suyos los argumentos mayoritarios esgrimidos en la anterior Sentencia de 2006, haciendo especial referencia a la misma y estableciendo una postura determinante en esa línea sobre la existencia de acceso carnal tanto cuando la víctima es penetrada, como cuando es el autor el que obliga o compele al sujeto pasivo a introducirle

Para el DRAE, acceso es equiparable a coito, y éste es definido como cópula sexual. Es claro que tales conceptos son aplicables tanto al varón como a la hembra, debiendo entenderse que en casos de cópula, o de introducción del miembro viril en las cavidades ya mencionadas, ambos participantes tienen acceso carnal. Concepto que, de otro lado, coincide con el socialmente aceptado de modo general. Finalmente, ha de tenerse en cuenta que la equiparación del acceso carnal violento con otras conductas se justifica en la similar potencialidad lesiva para el bien jurídico protegido. Así entendido el precepto, se plantea doctrinalmente la posibilidad de que la mujer sea sujeto activo del delito cuando la acción consiste en penetración del miembro viril. En la redacción del Código Penal anterior a 1989 tal cosa no era posible, pues el delito se cometía yaciendo con mujer y por yacer se entendía la introducción del pene en la vagina, con las precisiones jurisprudenciales que no es preciso recordar aquí. Como ya hemos dicho, no existe ninguna razón para que la protección del bien jurídico sea distinta en función del sexo del sujeto activo o del pasivo. Tampoco la conducta pierde significado o potencialidad lesiva para el bien jurídico si afecta a la libertad sexual en forma semejante, pudiendo tenerse en cuenta en este sentido la entidad y características de las conductas equiparadas. La cuestión, pues, se centra en determinar si el texto del artículo permite esa interpretación que equipara las agresiones. En este sentido, teniendo en cuenta la ampliación del concepto efectuada legalmente, nada impide entender que, al igual que el coito o la cópula sexual es predicable de ambos intervinientes, el acceso carnal existe siempre que haya penetración del miembro viril, sea cual sea el sexo del sujeto activo y del pasivo, de manera que el delito del artículo 179 lo comete tanto quien penetra a otro por las vías señaladas como quien se hace penetrar. Lo definitivo en estos casos sería la existencia del acceso carnal, determinado por la penetración, mediando violencia o intimidación, y resultando responsable de la agresión quien la utiliza o la aprovecha. Esta Sala llegó a esta conclusión tras el Pleno no jurisdiccional de 27 de mayo de 2005 , en el que acordó que a estos efectos "' es equivalente acceder carnalmente a hacerse acceder", acuerdo que ya ha sido aplicado en algunas sentencias como la STS $n^{\circ} 472 / 2006$, de 2 de mayo, en la que se dice lo siguiente: "La cuestión planteada por el recurrente ha dado lugar a una amplia polémica, doctrinal y jurisprudencial, fundamentalmente por la inicial redacción que el Código Penal de 1995 dio a los arts. 179 (agresión sexual) y 182 (abuso sexual), en los que hacía referencia y distinguía entre "acceso carnal" y "penetración bucal o anal", por lo que se entendia que si el sujeto activo "se introducía voluntariamente el órgano genital, en este caso, del menor, estaríamos ante el tipo básico del art. 178 ó 181, pues el tipo cualificado solo podía cometerlo "el que penetraba". 
alguno de sus miembros corporales por vía vaginal o anal, pudiendo ser el hombre o la mujer, sujeto activo o pasivo de estos delitos ${ }^{32}$.

\section{1.c. Subtipos agravados: artículo 183.4. Apartados a) a f).}

Analizados los apartados 1, 2 y 3 del art. 183 del CP, nos corresponde continuar con el apartado 4 de este artículo, donde se van a contemplar una serie de subtipos agravados, con penas superiores en grado a las previstas en los anteriores apartados, cualificados en función de la condición de la víctima -art. 183.4 a)-, de la condición del autor -art. 183.4 b), d) y f)-, y por último, en la forma de comisión del hecho -art. 183.4 c) y e)-.

El artículo 183.4 a) se apreciará respecto de las conductas previstas en los tres apartados anteriores, es decir, casos de abuso sexual, agresión sexual y acceso carnal por vía vaginal, anal o bucal e introducción de miembros corporales u objetos por las dos primeras vías, tanto sean constitutivos de abuso como de agresión: "Cuando el escaso desarrollo intelectual o físico de la víctima, o el hecho de tener un trastorno mental, la hubiera colocado en una situación de total indefensión y en todo caso, cuando sea menor de cuatro años".

En este apartado a), contempla una especial vulnerabilidad de la víctima en atención a las tres circunstancias descritas, haciendo a su vez dos apreciaciones, una con respecto a las dos primeras (escaso desarrollo intelectual o físico y trastorno mental), requiriendo que se hubiese colocado a la víctima en una situación de total indefensión con independencia de la minoría de edad, y con ello evitar una vulneración del principio non bis in ídem si, a su vez, se identificasen con elementos del tipo básico como la concurrencia de violencia o intimidación ${ }^{33}$. La segunda apreciación se hace con respecto a la tercera circunstancia (menor de cuatro años), cuando se precisa que será "en todo caso" cuando se contemple este subtipo agravado, no dejando margen este apartado a interpretación alguna por parte de jueces y tribunales ${ }^{34}$.

32 Vid. Sentencia del Tribunal Supremo, Sala de lo Penal, de 06/07/2018, no de Resolución 340/2018, Ponente: Antonio del Moral García, que citando la STS 699/2014, de 28 de octubre, establece que: "La sencillez con que se enuncia el problema -si hay acceso no solo cuando el sujeto activo del delito accede, sino también cuando obliga al sujeto pasivo a acceder-; es inversa a la intrínseca dificultad de alcanzar una solución que concite consenso. Lo demuestran las diversas posiciones mantenidas doctrinalmente; el examen de los argumentos blandidos en uno u otro sentido, basados no solo en la literalidad del texto legal sino también en razones de proporcionalidad; y las posturas enfrentadas que han convivido también en el seno de esta Sala Segunda- ".

33 Vid. Sentencia del Tribunal Supremo, Sala de lo Penal, de 17/09/2015, no de Resolución 530/2015, Ponente: Manuel Marchena Gómez: "Y es que, conforme a reiterada jurisprudencia de esta Sala, la locución " trastorno mental" no puede quedar circunscrita, por identificación, con los límites de la imputabilidad penal. Hemos dicho que aquella expresión "... quizás no demasiado afortunada, no reduce su ámbito de aplicación a la persona que padece genuinas enfermedades mentales, sino que debe ser interpretada en el sentido de que tienen cabida en la misma, todos aquellos supuestos en los que las deficiencias psíquicas permitan deducir razonablemente que quien las padece se encuentra impedido de prestar un consentimiento consciente y libre a aquello que se le propone" (STS 545/2000, 27 de marzo). Dicho con otras palabras, “... no se trata de una ausencia total de conciencia, sino de pérdida o inhibición de sus facultades intelectuales y volitivas, en grado o intensidad suficiente para desconocer $y$ desvalorar la relevancia de sus determinaciones, al menos en lo que atañen a impulsos sexuales trascendentes, aunque las tenga en otros aspectos relacionados con la vida doméstica o laboral (STS 331/2000, 3 de marzo). Como puede apreciarse, el factum incluye en la descripción del perfil de la víctima dos datos. Uno físico -la edad de 15 años- y otro psicológico -un retraso mental que la convierte en fácil destinatario de la interesada sugestión o influencia de terceros. Son, pues, dos factores los que convergen para intensificar un trastorno mental hasta el punto de nublar toda capacidad de autodeterminación en la esfera sexual."

34 Vid. Sentencia del Tribunal Supremo, Sala de lo Penal, de 24/09/2019, no de Resolución 418/2019, Ponente: Antonio del Moral García: "Para no incurrir en un prohibido bis in idem no se puede tomar en consideración 
En el artículo 183.4 b) se agravan los hechos en función de la condición del sujeto activo, en este caso, si se cometen por la actuación conjunta de dos o más personas. Este subtipo agravado se puede aplicar tanto a los abusos como a las agresiones sexuales, como a las conductas previstas en el artículo 183.3 del CP.

La razón de ser de este subtipo, que desde su introducción en el Código Penal de 1995 ha sufrido diversas reformas hasta llegar a su redacción actual, es castigar una conducta o conductas, donde la presencia de dos o más sujetos activos supondría asegurar la realización efectiva de la misma, facilitar la impunidad de aquellos, a la vez que produce una mayor intimidación en la víctima, agravando la situación. Así, lo manifiesta el TS, en su Sentencia de 24.11.2009, donde afirma que su fundamento estaría "no tanto en el acuerdo previo, sino fundamentalmente en la colaboración eficaz para el objetivo antijurídico querido que se patentiza en un incremento del desvalor de la acción y del resultado pues de un lado, la presencia de los copartícipes supone una acusada superioridad y una mayor impunidad o al menos aseguramiento del designio criminal para los autores, y una correlativa intensificación de la intimidación que sufre la víctima con efectiva disminución de toda capacidad de respuesta, dando lugar todo ello a un aumento cualitativo de la gravedad de la situación". ${ }^{35}$

En estos casos surgen problemas a la hora de valorar la participación de cada sujeto en la conducta delictiva, debiendo distinguir entre coautor y cooperador necesario, para ello, es nuevamente el TS el que establece que: "Es indudable que existiendo acuerdo previo entre las tres personas para cometer los delitos que analizamos, la participación en la ejecución de los hechos típicos obrando cada uno en cumplimiento del papel que se le hubiera asignado al confeccionar el proyecto delictivo, incluso cumpliendo órdenes y designios ajenos, les convierte a todos en coautores con arreglo a la teoría del dominio funcional del hecho". ${ }^{36}$

En este sentido, nos aclara que: "los mismos hechos probados evidencian que la responsabilidad criminal del acusado no se agota en las acciones típicas realizadas personalmente sobre la víctima -de las que ha de responder en concepto de autor material, según el párrafo primero del art. 28 C.P.-, sino que se extiende a las agresiones sexuales efectuadas por el otro partícipe, toda vez que respecto de éstas, el ahora recurrente interviene como cooperador necesario (art. 28 b) C.P.) en cuanto, según el relato fáctico, mantuvo el dominio del hecho, y coadyuvó sustancialmente en las violaciones ejecutadas por su compañero de fechoría. Es pacifica y constante la doctrina de esta Sala, según la cual "es cooperador necesario del artículo 14.3 (hoy, 28.b) del Código Penal el que contribuye o coadyuva al acceso carnal realizado por otro mediante la aportación del esfuerzo físico encaminado a doblegar la voluntad de resistencia de la víctima y también los que en la realización de un plan conjunto realizan una acción en cuyo desarrollo se realiza la violación, así como, en caso de no existir un previo plan preordenado, cuando

la agravación determinada por la edad. Si el tipo exige una edad inferior a los dieciséis años concluiríamos que muchas veces -la gran mayoría- habría abuso de superioridad pues el autor siempre será un joven o un adulto (al menos de dieciocho años). A mayor abundamiento y sobre todo, cuando el Código quiere establecer una edad por debajo de la cual ha de jugar la agravación fija la de cuatro años (art. 1834 a)."

35 Vid. Sentencia del Tribunal Supremo, Sala de lo Penal, de 22/09/2005, nº de Resolución 1142/2009, Ponente: Juan Ramón Berdugo Gómez de la Torre.

36 Vid. Sentencia del Tribunal Supremo, Sala de lo Penal, de 24/11/2009, no de Resolución 1091/2005, Ponente: Francisco Monterde Ferrer. 
varios individuos, con conciencia de la acción que se realiza, determinan con su presencia un efecto intimidatorio ambiental sobre la víctima de la violación materialmente realizada por otro agente (sentencias de 12 de Junio de 1.992, 23 de Enero de 1.993, 22 de Febrero y 24 de Mayo de 1.994 y 19 de Mayo de 1.995, 26 de febrero de 1.996, 17 de enero y 20 de julio de 2.001). ${ }^{37}$

Es objeto de controversia la continuidad delictiva cuando se producen sucesivos "accesos carnales" por diferentes sujetos para entender la existencia de un único delito continuado o bien la apreciación de tantos delitos como autores materiales. Con respecto a este matiz, de suma importancia para la delimitación de la pena, la jurisprudencia estima que: "Los ataques violentos a la libertad e indemnidad sexuales presentan características que los hacen ordinariamente identificables e individualizables respecto de otros similares, aun cuando se hayan cometido contra la misma persona. La intensidad de cada agresión como acción que lesiona un bien jurídico eminentemente personal y de gran valía para el ser humano, se refleja en la gravedad de las penas previstas por el Código Penal. Congruentemente, la jurisprudencia ha entendido en la mayoría de los casos y salvo supuestos muy excepcionales, que cuando se trata de agresiones sexuales, y muy especialmente cuando se trata del delito de violación, no es posible apreciar la continuidad delictiva. En este sentido se decía en la STS no 76/2006, de 31 de enero, citando otras muchas, que “...es doctrina de esta sala la exclusión, respecto de la figura del delito continuado, del llamado antes y ahora delito de violación -denominación (violación) aplicada en nuestros CP salvo en el periodo comprendido entre la entrada en vigor del CP 95 en su texto primitivo y la modificación del art. 179 producida por la LO 11/1999 que restableció esta designación-. Véanse en este sentido nuestras sentencias de 25.6.1977, 4.11.1978, 22.11.1979, 3.3.1984, 31.12.1985, 31.1.1986, 29.6.1988, 25.2.1991, 26.3.1991, 4.10.1993, 22.9.1995, 20.11.1995, 659/1996 y por citar otras más recientes, las 541/2001, 1316/2002, 462/2003 y 1192/2004 entre muchas otras. Con mayor razón se exceptúan los casos en los que son distintos los sujetos activos, pues el delito continuado se concibe como un supuesto de concurso real basado en la reiteración de la conducta por parte del mismo sujeto, y no en la agrupación de acciones u omisiones ejecutadas por distintos sujetos activos". ${ }^{38}$

El subtipo agravado del artículo 183.4 c) del CP también prevé el aumento de la pena "cuando la violencia o intimidación ejercidas revistan un carácter particularmente degradante o vejatorio" refiriéndose a las conductas previstas en los tres apartados anteriores -183.1, 183.2 y 183.3-, sin embargo, y según reiterada Jurisprudencia, se deduce que no cabría su apreciación en los apartados del art. 183.1 y $183.31^{\circ}$, dado que tal y

37 Vid. Sentencia del Tribunal Supremo, Sala de lo Penal, de 26/03/2003, nº de Resolución 462/2003, Ponente: Diego Antonio Ramos Gancedo. Abunda en esta línea, la STS, Sala de lo Penal, de 27/07/2009, nº de Resolución 849/2009, Ponente: Luciano Varela Castro: "Por lo tanto, cuando se trata de coautores nada impide la aplicación de la figura agravada a todos ellos por todos los hechos cometidos, pues en todos ellos se aprovecharon recíprocamente de las facilidades que supone la actuación conjunta, lo que a su vez denota una mayor antijuridicidad del hecho, justificando la exacerbación de la pena. Lo mismo ocurre cuando el autor se apoya para la ejecución en un cooperador que está presente en la escena de los hechos, pues entonces subsisten las razones de la agravación. Por el contrario, cuando intervienen dos personas y una de ellas es considerada cooperador necesario, no es posible aplicar a éste la agravación en su conducta, pues como hemos dicho, no puede concebirse la cooperación necesaria sin la presencia de al menos un autor a cuya ejecución coopera."

38 Vid. Sentencia del Tribunal Supremo, Sala de lo Penal, de 28/11/2007, no de Resolución 998/2007, Ponente: Miguel Colmenero Menéndez de Luarca. 
como se manifiesta en el propio subtipo, debe ir precedido de violencia o intimidación, hecho que no se contempla en estos últimos.

Así lo matiza el TS en Sentencia de 5 de febrero de 2018, donde afirma que "la jurisprudencia de esta Sala que viene precisando que ese carácter degradante, humillante o vejatorio ha de predicarse de la violencia o intimidación y no de los actos sexuales" 39 , por lo que, además, habrá que tener en cuenta las particulares circunstancias de la víctima, en función de su edad, desarrollo intelectual o físico o trastorno mental entre otros.

La agravación del apartado d) del art. $\mathbf{1 8 3 . 4}$ del CP es predicable de los arts. 183.1; 183.2 y 183.3: "Cuando, para la ejecución del delito, el responsable se haya prevalido de una relación de superioridad o parentesco, por ser ascendiente, o hermano, por naturaleza o adopción, o afines, con la víctima".

Si bien, este apartado diferencia entre "relación de superioridad o parentesco", vamos a establecer la distinción a nivel jurisprudencial, de modo que, el Tribunal Supremo, en Sentencia de 24 de septiembre de 2019, afirma que: "El art. 183.4 d) exige un prevalimiento que puede apoyarse en dos factores diferentes: una relación de superioridad o el parentesco. Como han subrayado los comentaristas no es que la superioridad tenga que apoyarse en el parentesco. La conjunción disyuntiva "o" que une ambas situaciones lo pone de manifiesto. Concurrirán los presupuestos de la agravante cuando haya un prevalimiento que puede basarse bien en el parentesco, bien en una relación de superioridad. Analicemos los dos términos de la agravación: a) En cuanto a la relación de superioridad se basaría en la cercanía cuasiparental que otorgaría una hegemonía anímica. Bien vistas las cosas eso no añade un plus a la superioridad derivada de la diferencia de edad, ya tomada en consideración en el tipo (menor de 16 años). Se refiere

39 Vid. Sentencia del Tribunal Supremo, Sala de lo Penal, de 05/02/2018, no de Resolución 62/2018, Ponente: Antonio Del Moral García. Sentencia que aclara estos conceptos al establecer: "La STS 1302/2006, de 18 de diciembre es buena muestra de esa pauta interpretativa. Subraya que "lo relevante es el carácter particularmente degradante o vejatorio de la violencia o intimidación presente en la agresión, pero no propiamente de los actos sexuales realizados en cualquiera de sus modalidades o variaciones, es decir, el 'plus' de antijuricidad que conlleva el subtipo agravado se refiere a la funcionalidad de los sustantivos violencia o intimidación. La jurisprudencia de esta Sala parte de la existencia inherente a toda agresión sexual de la vejación y humillación de la persona ofendida, exigiendo para configurar la agravación la concurrencia de un particular grado de brutalidad, degradación o vejación superior al inherente al hecho mismo, es decir, la presencia de fuerza o intimidación innecesarias por exceso, tanto en lo cuantitativo como en lo cualitativo (SSTS 530/01, 366/05 y 975/05 o 948/06)". Por su parte, la STS 709/2010, de 6 de julio expondrá: "Por ello, esta Sala viene reservando la aplicación del subtipo agravado a aquellos supuestos de especial brutalidad, salvajismo, humillación, degradación o vejación, de modo que para configurar la agravación que nos ocupa, exige la concurrencia de ese particular grado de brutalidad, degradación, vejación etc. superior al inherente al hecho mismo, es decir, la presencia de fuerza o intimidación innecesarias por exceso, tanto en lo cuantitativo como en lo cualitativo (STS 366/2005 ó 975/2005). Así la STS 11/2006, 19-01, precisa que es de tener en cuenta que la agravación del art. 180.1.1 a , no se refiere a los actos sexuales realizados, ya de por sí humillantes, vejatorios y degradantes, como decíamos, sino a la violencia o intimidación empleada en su ejecución, (STS 530/2001, 28-3). Y sólo será apreciable cuando la violencia o intimidación superen con claridad los niveles propios del delito, es decir, cuando, tal como se dice en el mismo artículo, revistan un carácter 'particularmente' degradante y vejatorio. Y ello porque lo que se castiga es el plus de antijuridicidad que representa el 'modus operandi' del autor cuando las concretas y especificas acciones instrumentales violentas o intimidatorias efectuadas, consideradas en su propia objetividad, hayan de calificarse como especialmente degradantes o vejatorias porque representen un cualificado menosprecio a la dignidad de la víctima. El legislador ha querido incluir en esta circunstancia, como agravante, la utilización, por el autor o autores, de elementos intimidantes graves, como puede ser un instrumento peligroso, y, como circunstancia añadida, además los comportamientos o actuaciones que, por su forma de consumar el delito, supongan además de la lesión a la libertad e indemnidad sexual, un mayor agravio consistente en haber realizado el hecho de manera que entraña una mayor vejación o degradación aumentando su sufrimiento ( STS 1005/2009)". 
más bien a un abuso de confianza que es algo distinto del abuso de superioridad (como demuestra que en el art. 22 CP aparezcan como dos agravaciones diferenciadas). Además -aunque podamos imaginar algún supuesto en que no será así necesariamente-en principio introducir por la vía del inciso inicial de esta norma (superioridad), lo que ha sido deliberadamente expulsado del inciso segundo (parentesco) tiene algo de fraude interpretativo: es decir, considerar que todo parentesco o relación asimilable no expresamente mencionada en el inciso final representa una relación de superioridad que colmaría las exigencias del inciso inicial. Si fuese así, sobraría la segunda parte del precepto. b) Pasemos a examinar el parentesco. La dicción del Código no es muy afortunada por la perturbadora referencia sin matices a la afinidad. Aqui eso no nos afecta en tanto que sencillamente no hay parentesco. Se habla de ascendientes, descendientes, o hermanos por naturaleza o adopción y afines. Es claro que no está comprendido ni el tío carnal, ni el afín, ni menos la pareja afectiva del tío o tía. El parentesco colateral está excluido, salvo el caso de hermanos". 40

Esta agravación exige no sólo la existencia de una situación de superioridad, sino además, que el sujeto activo se prevalezca de ella, por ello, en algunos casos, se tendrá en cuenta la edad como otro factor más para la configuración del tipo ${ }^{41}$.

Con respecto a la agravación por parentesco, hemos de destacar la diferencia con respecto a lo recogido en el artículo 23 del CP, excluyendo, de su ámbito de aplicación, por razones obvias, al cónyuge o asimilado y a los descendientes, recurriendo, en todo caso, a la agravante genérica en esas circunstancias ${ }^{42}$.

40 Vid. Sentencia del Tribunal Supremo, Sala de lo Penal, de 24/09/2019, nº de Resolución 418/2019, Ponente: Antonio del Moral García.

41 Vid. Sentencia del Tribunal Supremo, Sala de lo Penal, de 20/11/2015, no de Resolución 626/2015, Ponente: Juan Saavedra Ruíz: "Pues bien, sentado que el prevalimiento o abuso de superioridad se refiere a la ejecución del hecho y no al consentimiento de la víctima, la cuestión estriba en establecer si la circunstancia declarada probada de estrecha relación y confianza del acusado con la víctima supone una añadido de antijuricidad que justifica la aplicación del subtipo agravado. La respuesta en el caso debe ser afirmativa, por cuanto en palabras del Tribunal provincial, además de la diferencia de edad entre sujeto activo y pasivo del delito, evidente relación de superioridad, "la existencia de unas estrechas relaciones con la familia de la víctima que determinaban confianza por parte de ésta y el aprovechamiento de estos extremos para cometer los delitos.....garantizó la falta de control por parte de los padres, quienes pensando que tan buen amigo estaba leyendo un cuento a su hijo no pudieron sospechar hasta que relató los hechos, que en el piso segundo de su casa se estaban produciendo esos acontecimientos". El razonamiento es correcto porque en el contexto de una relación "cuasi familiar" el acusado se prevale, es decir, abusa de una relación que le otorgaba superioridad sobre el menor, derivada de la confianza a la que nos hemos referido más arriba, lo que facilita la ejecución del delito calificado, justificando el plus de penalidad añadido al tipo básico previsto en el artículo 183.1 y 3 CP."

42 Vid. Sentencia del Tribunal Supremo, Sala de lo Penal, de 14/10/2005, $\mathrm{n}^{\circ}$ de Resolución 1197/2005, Ponente: Julián Artemio Sánchez Melgar: "No obstante, la modificación del artículo 23 del Código penal, en la fecha indicada, y vigente ya en el momento de producirse estos hechos, dice textualmente: "es circunstancia que puede atenuar o agravar la responsabilidad, según la naturaleza, los motivos y los efectos del delito, ser o haber sido el agraviado cónyuge o persona que esté o haya estado ligada de forma estable por análoga relación de afectividad, o ser ascendiente, descendiente o hermano por naturaleza o adopción del ofensor o de su cónyuge o conviviente" ( LO 11/2003, de 29 septiembre, de medidas en materia de seguridad ciudadana, violencia doméstica e integración social de los extranjeros, que entró en vigor el día 1 de octubre de 2003). La jurisprudencia de este Tribunal ha de cambiar necesariamente merced a la modificación legislativa operada, pues se objetiva su aplicación, de modo que concurre, con los tradicionales efectos agravatorios en delitos contra la vida e integridad fisica de las personas, aunque haya desaparecido el matrimonio o esa relación de análoga afectividad, por expresa determinación del legislador (art. 117 de la Constitución española: imperio de la ley), siempre, claro está, que los hechos estén relacionados con dicha convivencia, directa o indirectamente, no en supuestos de ajena perpetración, es decir, cuando nada tenga que ver con temas relacionados con tal convivencia o sus intereses periféricos." 
También, se ha de acotar el término afinidad para evitar problemas de interpretación, de modo que la Jurisprudencia establece: "Como indicábamos en nuestra sentencia 69/2014, de 3 de febrero, no hay que forzar mucho las cosas para entender que, aunque gramaticalmente mal expresado, para la agravación especifica que contemplamos, la consanguinidad, la adopción y la afinidad, se están equiparando en la Ley únicamente en los supuestos de un mismo grado de vinculación, esto es, que la equiparación se produce respecto de los grados equivalentes a los ascendientes, descendientes o hermanos, que no son otros que los suegros, los cuñados y los hijastros, quedando fuera de la agravación quienes tienen la lejana vinculación de sobrino-nieto por afinidad." 43

A veces, la imposibilidad de apreciar la agravante de parentesco por no poder incluirse la relación como tal dentro de los supuestos establecidos en el subtipo, hace posible la aplicación de la agravante de abuso de superioridad por la facilidad que le otorga al sujeto activo tener ciertos lazos familiares con la víctima para la realización de la conducta delictiva ${ }^{44}$.

En esta línea se manifiesta el TS, en Sentencia de 28/10/2015, no de Resolución: 634/2015, Ponente: Miguel Colmenero Menéndez de Luarca: "Este precepto considera como una circunstancia de agravación que, para la ejecución del delito, el responsable se haya prevalido de una relación de superioridad o parentesco por ser ascendiente, descendiente o hermano, por naturaleza o adopción, o afines, con la víctima. Se basa en la mayor gravedad de la conducta en atención a las facilidades de que dispone el autor para superar la eventual negativa de la víctima que se derivan de la relación parental. A diferencia del artículo 23 , en el que se regula la circunstancia mixta de parentesco, no se tiene en cuenta a esos efectos la existencia de una relación análoga de afectividad. El artículo 23 establece que puede atenuar o agravar la responsabilidad ser o haber sido el agraviado cónyuge o persona que esté o haya estado ligada de forma estable por análoga relación de afectividad con el ofensor. O bien ser ascendiente, descendiente o hermano por naturaleza o adopción del ofensor o de su cónyuge o conviviente. En el primer caso se trata, pues de un subtipo agravado, en el que la pena tipo queda comprendida entre siete años $y$ diez años de prisión. Dentro de esos límites se aplicarán las reglas relativas a la concurrencia de atenuantes y agravantes. En el segundo caso, cuando se aplica la circunstancia de parentesco, se aplican las reglas que determinan los efectos de las circunstancias en general."

43 Vid. Sentencia del Tribunal Supremo, Sala de lo Penal, de 24/01/2019, nº de Resolución 724/2019, Ponente: Pablo Llarena Conde: "El código penal, en una redacción original, contempló como agravación específica para los abusos sexuales tipificados en el artículo 181 del Código Penal, cuando el autor se prevaliera de una situación de superioridad manifiesta que coartare la libertad de la víctima; una circunstancia que, con ocasión de la LO 11/1999, se concretó a aquellos supuestos en que el responsable se prevalga de una relación de superioridad o parentesco, por ser ascendiente, descendiente o hermano, por naturaleza o adopción, o afines, con la víctima. La redacción ha sido censurada por la imprecisión del inciso final relativo a los afines del sujeto activo. Ante ello, la jurisprudencia de esta Sala proclama que, puesto que la agravación derivada del parentesco sólo es concurrente cuando, hablando de consanguinidad y adopción, el autor es ascendiente, descendiente o hermano de la víctima, no tendría sentido que se apreciara literalmente la agravación respecto de todos los afines sin limitación. Sería absurdo entender que el parentesco colateral por consanguinidad esté excluido para la agravación de la responsabilidad, salvo en el caso de los hermanos, y que sin embargo se abarque todo el parentesco colateral por afinidad, cualquiera que sea el grado de unión entre el agresor y su víctima. En este sentido: STS, de 28/10/2015, $\mathrm{n}^{\text {o }}$ de Resolución: 634/2015, Ponente: Miguel Colmenero Menéndez de Luarca: "En el caso, la persona agraviada es hija de quien convive con el ofensor, lo que justificaría la apreciación de la agravante de parentesco, cuya aplicación interesó el Ministerio Fiscal. Pero el recurrente no es ascendiente por afinidad con la víctima, pues no existe vínculo matrimonial con la madre de ésta y no está prevista legalmente la consideración de una análoga relación de afectividad a estos efectos. Desde esa perspectiva del parentesco, no sería aplicable el artículo 181.5 en relación con el 180.1.4."

44 Vid. Sentencia del Tribunal Supremo, Sala de lo Penal, de 11/07/2018, $\mathrm{n}^{\mathrm{o}}$ de Resolución 351/2018, Ponente: Vicente Magro Servet: "Esta Sala del Tribunal Supremo en Sentencia 393/2009 de 22 Abr. 2009, Rec. 11263/2008 señaló que: "El art. 180.1.4 sanciona como agravante especifica de la agresión sexual cuando el responsable se haya prevalido de una relación de superioridad o parentesco por ser ascendiente, descendiente, hermano, por naturaleza o adopción, o afines con la víctima. De acuerdo con el texto original del art. 180 C.P de 1.995 este subtipo agravado se cometía únicamente cuando se trataba del prevalimiento por la relación familiar entre sujetos activo y pasivo que previene el precepto. Pero la L.O. 11/1999 ha extendido el prevalimiento que sustenta el tipo 
El subtipo agravado del artículo 183.4 e) del CP es aplicable a los primeros tres apartados del artículo 183, en claro paralelismo con lo contemplado en el artículo 180.1.5 $5^{\circ} \mathrm{del}$ CP.

Con anterioridad a la reforma del Código Penal, por LO 15/2015, de 30 de marzo, se hacía referencia únicamente a "la puesta en peligro de la vida del menor", mientras que a partir de dicha reforma, se añade "la puesta en peligro, de forma dolosa o por imprudencia grave, de la vida o salud de la víctima". Con ello, se incluyen dos nuevos bienes jurídicos a proteger, es decir, ya no sólo se trata de la protección de la indemnidad sexual, sino también, la vida y la salud de las víctimas, siendo además que se han de poner en peligro de forma dolosa o por imprudencia grave, excluyendo la imprudencia menos grave.

Ello hace que entendamos, como bien aclara la Jurisprudencia, que el peligro para la vida o salud ha de ser concreto, así se lo establece en la Sentencia del TS de 10/11/2010: “...Por eso, venimos diciendo con reiteración que lo importante a estos efectos no es el concreto instrumento utilizado, sino el uso que se le dé, o el peligro concreto creado al respecto (...)" 45 .

a cualquier otra relación de superioridad, como de índole laboral, docente, económica, de edad o de otra similar. En ambas modalidades de prevalimiento típicas, el denominador común es una situación de superioridad por parte del agente y de inferioridad de la víctima, la desproporción o asimetría entre las posiciones de ambos, lo que determina por sí misma la presión coactiva que condiciona y debilita la libertad para decidir de la víctima, de lo que se aprovecha el autor para realizar la conducta delictiva con mayor facilidad, lo que puede determinar-como de hecho sucede con frecuencia- un menor contenido en la intimidación, precisamente por el aprovechamiento de aquella situación de preeminencia del autor y de subordinación y dependencia de la víctima generada en este caso por el vínculo familiar .... Es esa situación de superioridad producida por la relación parental la que fundamenta la aplicación del subtipo agravado apreciado por el Tribunal de instancia". En este caso el abuso de superioridad es obvio, ya que en el desarrollo de los hechos se aprovecha de su vínculo familiar para tener acceso con la menor y vencer su resistencia, tanto por la diferencia de edad que existía y por esa relación familiar que le hacía vencer la inicial resistencia ya que en ambas ocasiones en que se perpetra la agresión sexual la introduce en el vehículo y valiéndose nuevamente de la ascendencia que sobre ella tenía por esa relación familiar la penetra vaginalmente en ambas ocasiones venciendo su resistencia y pese a su llanto, y ello aprovechándose de su superioridad, circunstancia concurrente en este tipo de casos, al no quedar excluida la agravación solo a padres, hijo o hermanos, ya que se refiere a "situación de superioridad o parentesco". En cualquier caso no tiene incidencia en cuanto a la penalidad ya establecida en un tope de 20 años de prisión, y en el primer caso ya se ha aplicado la continuidad delictiva con apreciación de la penalidad de la agresión sexual en la que concurre el art. $180.1 .4^{\circ}$ por el prevalimiento que lleva la pena a 14 años de prisión y 13 años de prisión en el segundo delito de agresión sexual con la concurrencia del prevalimiento del art. $180.1 .4^{\circ} \mathrm{C}$ en la relación de superioridad acreditada y constatada.."

45 Vid. Sentencia del Tribunal Supremo, Sala de lo Penal, de 10/11/2010, nº de Resolución 958/2010, Ponente: Juan Ramón Berdugo Gómez de la Torre: “...exclusión de aquellos casos en que el arma o medio peligroso se utiliza sólo para exhibirlo, de modo que la víctima quede intimidada al conocer el elemento de que dispone su agresor. Enseñar el arma de fuego, el arma blanca o el instrumento útil para otras cosas pero que puede causar lesiones por su uso espurio, como un destornillador, un martillo, una maza o simplemente una garrota o un palo, y no utilizarlo después en la agresión realizada, se considera que no basta a los efectos de la cualificación que estamos examinando. Sin embargo, cuando se acomete usando ese arma o medio peligroso, incluso cuando la acometida no alcance el cuerpo de la víctima, ha de aplicarse esta circunstancia $5^{a}$. Y lo mismo ha de hacerse cuando se acerca el instrumento a alguna zona particularmente sensible a los efectos de poder causar la muerte o lesiones graves, como ocurre cuando se coloca un arma blanca o medio semejante junto al cuello o el abdomen, o una pistola apuntando a la cabeza, tórax o también al cuello o al abdomen. La STS. 1081/2004 de 30.9, ya recordó que una intimidación que sea de por sí suficientemente intensa para superar la natural resistencia de la víctima ante un ataque de este tipo, es ya consustancial al tipo básico, (STS nº 431/1999, de 23 de marzo), si se tienen en cuenta los bienes jurídicos atacados por la conducta del autor. En este sentido, la mera exhibición del arma no llenaría las exigencias para la aplicación de la agravación".

En este sentido se manifiesta el TS, en Sentencia de 10/10/2006, no de Resolución: 971/2006, Ponente: Andrés Martínez Arrieta: "La agravación se concreta en la utilización de armas susceptibles de causar la muerte o alguna de las lesiones de los arts. 149 y 150 del Código penal. Esta redacción típica ha resuelto antiguas concepciones 
Es la Sentencia del TS de 10/10/2012, la que hace un análisis exhaustivo de lo anteriormente expuesto, explicando a su vez la imposibilidad, en determinados casos, de vulneración del principio "non bis in idem", y a su vez del principio de legalidad, a la hora de la delimitación entre el tipo básico y el tipo agravado al que nos referimos, con clara referencia a la protección de la vida o salud: "Esta interpretación restrictiva de la agravación tiene en cuenta que el legislador relaciona el uso del arma o instrumento peligroso, con la potencialidad de causar la muerte o lesiones agravadas, por lo que considera como objeto de protección no solo la libertad sexual, sino la vida y la integridad física. Por ello, señala la STS núm. 1667/2002, de 16 de octubre: "lo determinante no es solamente el "instrumento", sino el "uso" que el sujeto activo haga del mismo, de tal manera que la mera exhibición del instrumento no es suficiente para integrar el subtipo agravado, cuando no se aprecie un peligro especialmente relevante y constituya el único elemento que integra la intimidación”. De forma más concreta la sentencia la STS $843 / 2008$, de 5 de diciembre, precisa que el subtipo agravado debe apreciarse cuando el arma o instrumento peligroso "se usa desencadenando además del efecto intimidatorio, un riesgo potencial real de menoscabo de la integridad física”. Cuando se trata de armas blancas, la doctrina jurisprudencial ha apreciado el subtipo agravado en los casos en los que el autor colocó el cuchillo o navaja en zonas corporales en las que, además de la intimidación, la víctima ha podido temer por su vida o su integridad física y no sólo su libertad (SSTS 13 de octubre de 1999 y 28 de enero de 2005). Por ejemplo en supuestos en los que el autor colocó el arma en el cuello de la víctima (STS núm. 1991/2000, de 19 de diciembre; STS núm. 752/2002, de 29 de abril y STS núm. 1667/2002, de 16 de octubre); o en el costado o en el abdomen (STS núm. 752/2002). Es decir que en caso de utilización de armas blancas, debe apreciarse el subtipo agravado cuando el autor sitúa el cuchillo o navaja tocando zonas corporales sensibles de la víctima". ${ }^{46}$

Además de lo manifestado, surgen problemas a la hora de apreciar la compatibilidad en la aplicación de este subtipo agravado y la posible concurrencia de un delito contra la vida o salud. De lo manifestado en reiterada Jurisprudencia se deduce la posible compatibilidad entre ambos, dado los distintos bienes jurídicos afectados, aunque se ha de valorar cada caso concreto para determinar las circunstancias del mismo: "El recurrente pretende abarcar en el delito de agresión sexual las lesiones causadas en su totalidad, pero ello no es posible. Así, esta Sala ha señalado (entre otras, y como reciente, la Sentencia 13/2019 de 17 Ene. 2019, Rec. 10416/2018), en cuanto: "Ciertamente una reiterada jurisprudencia, por todas las SSTS 892/2008, 11-12; 1305/2003, 6-11, citada por la STS 886/2005, 5-7; 673/2007, 19-7, apunta que cuando el menoscabo de la integridad corporal o de la salud fisica se ha producido como consecuencia de la violencia empleada para vencer la resistencia de la víctima al ataque contra su libertad sexual, el régimen de concurso es el del concurso real y ello porque el delito de violación requiere el empleo de violencia, pero no exige la causación de lesiones corporales, de modo que

sobre esta agravación en la que bastaba el empleo de un arma para la subsunción en la agravación propiciando interpretaciones subjetivas en las que lo relevante era el contenido intimidatorio derivado del empleo de un arma, con independencia de que fuera real o simulada, pues lo relevante era la intimidación realizada. La redacción típica de la agravación, en la redacción vigente, exige que el arma empleada sea potencialmente lesiva, no sólo como efecto intimidatorio, sino a la integridad fisica."

46 Vid. Sentencia del Tribunal Supremo, Sala de lo Penal, de 10/10/2012, no de Resolución 741/2012, Ponente: Cándido Conde-Pumpido Touron. 
el ataque a la salud y a la integridad corporal protegidos por el tipo de lesiones no es elemento indispensable del delito contra la libertad sexual". ${ }^{47}$

El último apartado del artículo 183.4, punto f), contempla la obligación de aplicar como agravante el hecho de que "la infracción se haya cometido en el seno de una organización o de un grupo criminal que se dedicare a la realización de tales actividades". Obligación que viene impuesta por la normativa europea, ya que el artículo 5 de la Decisión Marco 2004/68/JAI del Consejo de Europa ${ }^{48}$, establece como sanciones y circunstancias agravantes, "que la infracción se haya cometido en el marco de una organización delictiva según la definición de la Acción Común 98/733/JAI"49.

Este subtipo, que se podrá aplicar a cualquiera de los delitos de agresión y abuso sexual, se ha de ajustar a lo que los artículos 570 bis y 570 ter del CP entienden por organización y grupo criminal $^{50}$, de manera que mientras la primera parece que goza de cierta estabilidad, el segundo se crea para actuaciones concretas.

En este sentido, la jurisprudencia ha interpretado que para considerar una organización delictiva "no basta el mero concierto de varias personas para la realización de una determinada infracción criminal, y se necesita como declara la Sentencia de 6 de octubre de 2003, que el acuerdo lleve a la formación de una estructura, siquiera sea elemental, en que haya una dirección y una jerarquía que planifique y conjunte las diversas actividades de los miembros del grupo (...) más allá de un mero acuerdo transitorio dirigido a una particular acción delictiva, aparece una organización estable, jerarquizada, y con distribución de funciones, es decir un entramado de personas que ejercían papeles

47 Vid. Sentencia del Tribunal Supremo, Sala de lo Penal, de 04/07/2019, n ${ }^{\circ}$ de Resolución 349/2019, Ponente: Vicente Magro Servet: “...Así, se ha señalado (STS 2047/2002, 10-12), que "la violación solamente consume las lesiones producidas por la violencia cuando éstas pueden ser abarcadas dentro del contenido de ilicitud que es propio del acceso carnal violento, por ejemplo, leves hematomas en los muslos o lesiones en la propia zona genital, no ocasionados de modo deliberado sino como forzosa consecuencia del acceso carnal forzado". Pero cuando se infieren lesiones deliberadas y adicionales, como medio de vencer la resistencia de la víctima, pero con entidad sustancial autónoma, procede la aplicación de lo dispuesto en el art. 73 y, en su caso, del art. 77 CP, en función del tipo de concurrencia, en este supuesto no discutido". Por su parte, la STS 625/2010, de 6 de julio advierte que "esta doctrina impone el examen detenido de cada supuesto en particular para comprobar, de un lado, si las lesiones sufridas por la víctima fueron una consecuencia derivada directamente de la misma agresión sexual, en cuyo caso quedarían absorbidas por ésta y, de otro, si la violencia ejercida para doblegar o vencer la resistencia de la persona atacada superó los límites mínimos necesarios para entender que concurrió la violencia contemplada en la descripción del tipo objetivo de la agresión sexual, sancionando independientemente aquello que la exceda". Es posible el concurso real entre los delitos de agresión sexual y lesiones cuando éstas últimas no son el medio comisivo para lograr la penetración típica. Pero cuando constituyen el mecanismo a través del cual se consigue el trato carnal estaremos ante un concurso medial (subespecie del real, tradicionalmente asimilado al ideal)".

48 Vid. decisión Marco 2004/68/JAI del Consejo de 22 diciembre 2003, relativa a la lucha contra la explotación sexual de los niños y la pornografía infantil (Diario Oficial de la Unión Europea) L 13/44 de 20 de enero 2004.

49 Vid. Acción Común de 21 diciembre 98, adoptada por el Consejo sobre la base del artículo K.3 del Tratado de la Unión Europea, relativo a la tipificación penal de la participación en una organización delictiva en los Estados miembros de la Unión Europea.

50 Vid. Artículo 570 bis 1 in fine del actual Código Penal español: "A los efectos de este Código se entiende por organización criminal la agrupación formada por más de dos personas con carácter estable o por tiempo indefinido, que de manera concertada y coordinada se repartan diversas tareas o funciones con el fin de cometer delitos."

Artículo 570 ter 1 in fine CP: "A los efectos de este Código se entiende por grupo criminal la unión de más de dos personas que, sin reunir alguna o algunas de las características de la organización criminal definida en el artículo anterior, tenga por finalidad o por objeto la perpetración concertada de delitos." 
distintos en una actividad permanente y estable para la obtención continuada de beneficios económicos". ${ }^{51}$

Esta cualificación se justifica porque la delincuencia organizada suele actuar con frecuencia en relación a delitos que afectan a menores (abusos, prostitución, trata de seres humanos, pornografía, corrupción de menores, etc.).

El apartado quinto y último del artículo 183 del CP suma, para agravar la pena, a todo lo tipificado en este artículo, el hecho de que "el culpable se hubiera prevalido de su condición de autoridad, agente de ésta o funcionario público". Esta cualificación ha sido introducida por la LO 5/2010, de 22 de junio de modificación del CP, en el ámbito de los delitos sexuales, aunque la nueva redacción es más amplia, porque incluye no sólo el prevalimiento de la condición de "funcionario público", sino también de "agente de ésta" o "autoridad".

Según reiterada Jurisprudencia debe el sujeto beneficiarse de su condición de autoridad pública para así ejecutar el delito con mayor facilidad o menor riesgo y que esa condición se ponga al servicio del propósito criminal: "Esta Sala ha precisado (SSTS 984/1995, de 6 octubre y 2 de diciembre de 1997) que la agravante encuentra su fundamento, en el abuso de superioridad en el plano moral, utilizado en beneficio particular por el delincuente y requiere que se ponga el carácter público al servicio de los propósitos criminales. Requiere, en consecuencia, reunir la condición de funcionario público, y poner tal condición al servicio de su propósito criminal, aprovechando las ventajas que el cargo le ofrece para ejecutar el hecho delictivo con mayor facilidad y menor riesgo (v. SSTS 5-12-1973, 18-10-1982, 30-10-1987 y 25-10-1988, fundamentalmente). La jurisprudencia ha aplicado esta agravante en relación con funcionarios policiales en las Sentencias de 18 de mayo de 1993, 24 de noviembre de 1995 y 14 de febrero de 1998. La STS de 19-10-2001, no 1890/2001, aplicó la agravante al caso en que el recurrente hizo valer su condición de funcionario de policía para intervenir en los hechos, exhibiendo su placa reglamentaria, aprovechándose de ese abuso de superioridad en el plano moral que tal condición le proporcionaba..." ${ }^{52}$

\section{ANÁLISIS DEL ANTEPROYECTO SOBRE DELITOS SEXUALES DE LEGE FERENDA}

En nuestra introducción, hicimos referencia a la necesidad de cambios legislativos con respecto a los delitos sexuales recogidos en el Título VIII, Libro II de nuestro Código Penal, debido, fundamentalmente, a la alarma social que determinados casos habían suscitado en nuestro país.

De ahí que, en la actualidad, hayan surgido algunas proposiciones de reforma en este sentido. Como destacables, debemos hacer referencia a las proposiciones de grupos parlamentarios de distinta índole que dan lugar al Anteproyecto de Ley Orgánica de Garantía Integral de la Libertad Sexual, de 3 de Marzo de 2020, que ha quedado paralizado

51 Vid. Sentencia del Tribunal Supremo, Sala de lo Penal, de 02/03/2010, $\mathrm{n}^{\mathrm{o}}$ de Resolución 330/2010, Ponente: Adolfo Prego de Oliver Tolivar.

52 Vid. Sentencia del Tribunal Supremo, Sala de lo Penal, de 23/11/2005, no de Resolución 1438/2005, Ponente: Francisco Monterde Ferrer. 
dada la situación actual en la que nos encontramos inmersos debido a la pandemia existente.

Este Anteproyecto consta de un Título preliminar, ocho Títulos, una disposición adicional, una disposición transitoria, una disposición derogatoria y veinte disposiciones finales, adoptando una perspectiva integral y novedosa en el ámbito de las violencias sexuales que se materializa en la modificación de las disposiciones del ordenamiento jurídico necesarias para llevar a efecto los objetivos y principios de esta Ley ${ }^{53}$.

En definitiva, lo que parece pretender es colocar a la mujer como titular indiscutible de derechos humanos, incluyendo una "perspectiva de género e interseccionalidad" con el fin de lograr la igualdad en todos los ámbitos. Llama la atención, el hecho de que se personifique, en la mayor parte del texto, a la víctima como "mujer", de manera que se excluyan a los menores y personas con discapacidad necesitadas de especial protección. Muestra de ello son las diferentes referencias que el propio Anteproyecto hace de esta exclusión, sirva como ejemplo lo que en el artículo 1.1 del Título Preliminar se establece en cuanto al objeto y finalidad de la ley: "La presente Ley tiene por objeto la protección integral del derecho a la libertad sexual de todas las personas mediante la prevención y la erradicación de todas las violencias sexuales, que afectan a las mujeres de manera desproporcionada, como manifestación de la discriminación, la situación de desigualdad y las relaciones de poder de género".

Cabe mencionar que esta ley recurre en determinados puntos, pese a hacer una equiparación entre víctima y mujer de manera generalizada, a ampliar el concepto de víctima a menores y otras personas vulnerables, así se establece en la Disposición final décima, apartado noveno, sobre Modificación de la Ley 4/2015, de 27 de abril, del Estatuto de la víctima del delito: "Nueve. Se modifica el artículo 26, que quedará redactado como sigue: "Artículo 26. Medidas de protección para menores, personas con discapacidad necesitadas de especial protección y víctimas de delitos contra la libertad e indemnidad sexual. 1. En el caso de las víctimas menores de edad, víctimas con discapacidad necesitadas de especial protección, y víctimas de delitos contra la libertad sexual, además de las medidas previstas en el artículo anterior se adoptarán, de acuerdo con lo dispuesto en la Ley de Enjuiciamiento Criminal, las medidas que resulten necesarias para evitar o limitar, en la medida de lo posible, que el desarrollo de la investigación o la celebración del juicio se conviertan en una nueva fuente de perjuicios para la víctima del delito.(...) ",54.

Se produce así, a nuestro entender, cierta confusión en cuanto al sujeto a proteger en estos casos, tal y como se indica en el Título Preliminar, artículo 3.2: "Su ámbito de aplicación subjetiva comprende a todas las mujeres, desde los 16 años, que hayan sido

53 Vid.https://files.mediaset.es/file/10002/2020/03/04/anteproyecto_libertad_sexual_marca_de_agua_3d42.pdf "Anteproyecto de Ley Orgánica de Garantía Integral de la Libertad Sexual".

54 Vid.https://files.mediaset.es/file/10002/2020/03/04/anteproyecto_libertad_sexual_marca_de_agua 3d42.pdf "Anteproyecto de Ley Orgánica de Garantía Integral de la Libertad Sexual”, p.58. Sirva como reiteración de lo manifestado, el apartado segundo de la Disposición final decimotercera sobre Modificación del Real Decreto de 14 de septiembre de 1882, aprobatorio de la Ley de Enjuiciamiento Criminal, p. 66: "Dos. Se modifica el apartado 3 del artículo 681 que queda redactado como sigue: Artículo 681. 3. Queda prohibida, en todo caso, la divulgación o publicación de información relativa a la identidad de víctimas menores de edad, de víctimas con discapacidad necesitadas de especial protección y de las víctimas de los delitos contra la libertad sexual, de datos que puedan facilitar su identificación de forma directa o indirecta, o de aquellas circunstancias personales que hubieran sido valoradas para resolver sobre sus necesidades de protección, así como la obtención, divulgación o publicación de imágenes suyas o de sus familiares" 
víctimas de violencias sexuales: (...)”. Por ello, cabría preguntarse en qué situación se encontrarían los varones menores de edades comprendidas entre 16 y 18 años, así como los menores de edad inferior a 16 años.

Como punto central de esta reforma, y en torno al cual girarán todas las modificaciones, se encuentra la eliminación de la distinción entre agresión y abuso sexual: “(...) considerándose agresiones sexuales todas aquellas conductas que atenten contra la libertad sexual sin el consentimiento de la otra persona, cumpliendo así España con las obligaciones asumidas desde que ratificó en 2014 el Convenio de Estambul. Esta equiparación, además de atenuar problemas probatorios, evita la revictimización o la victimización secundaria". Esta última referencia para evitar la revictimización o la victimización secundaria, no olvida la protección penal del bien jurídico protegido, al igual que tampoco olvida los fines de las penas en cuanto, manifiesta el Anteproyecto, a “(...) implementar en los establecimientos penitenciarios vías que permitan la reinserción social del condenado por estos delitos". ${ }^{55}$ En definitiva, viene a establecer que "Se entenderá que no existe consentimiento cuando la víctima no haya manifestado libremente por actos exteriores, concluyentes e inequívocos conforme a las circunstancias concurrentes, su voluntad expresa de participar en el acto". ${ }^{56}$

Este Anteproyecto basa toda su redacción y fundamento en el artículo 149.1 CE, por el cual "el Estado tiene competencia exclusiva en la regulación de las condiciones básicas que garanticen la igualdad de todos los españoles en el ejercicio de los derechos y en el cumplimiento de los deberes constitucionales". El motivo de este fundamento y su tramitación como Ley Orgánica se debe a que las leyes orgánicas se refieren al desarrollo de los derechos fundamentales y de las libertades públicas. ${ }^{57}$

\section{CONCLUSIONES FINALES}

La evolución histórico-legislativa de una sociedad conlleva cambios políticos, económicos, sociales y tecnológicos que determinan la necesidad en los ciudadanos de sentirse protegidos y confiar en que el sistema funcione a la perfección. El legislador debe recoger esas necesidades sociales y plasmarlas en leyes para que se ajusten a la realidad. Por ello, la protección de las víctimas más vulnerables, como son los menores, nos interesa, de manera especial, por la alarma social que suscitan reiteradas acciones delictivas en la actualidad.

Tras la evolución histórico-legislativa necesaria para la comprensión de los cambios y estudio de los elementos propios del tipo, entendemos, desde el punto de vista penal, la delimitación del bien jurídico protegido de manera práctica, esto es, caso a caso, de manera que en un determinado delito puedan confluir varios bienes jurídicos, siendo la

55 Vid. https://files.mediaset.es/file/10002/2020/03/04/anteproyecto_libertad_sexual_marca_de_agua_3d42.pdf "Anteproyecto de Ley Orgánica de Garantía Integral de la Libertad Sexual”, p.11.

56 Vid. https://www.lamoncloa.gob.es/consejodeministros/referencias/Paginas/2020/refc20200303.aspx) "Tramitación del ANTEPROYECTO DE LEY ORGÁNICA de garantía integral de la libertad sexual, a los efectos previstos en el artículo 26.4 de la Ley 50/1997, de 27 de noviembre, del Gobierno.", p.12.

57 Vid. Artículo 81.1 CE: "Son leyes orgánicas las relativas al desarrollo de los derechos fundamentales y de las libertades públicas, las que aprueben los Estatutos de Autonomía y el régimen electoral general y las demás previstas en la Constitución”. 
premisa mayor, la libertad sexual, y en el ámbito de menores, la indemnidad sexual, con la posibilidad de añadir la dignidad, la integridad o la propia vida como bienes jurídicos a proteger.

La cuestión, como se ha podido apreciar, es mucho más compleja de lo que parece, dado las diferentes, y a veces contradictorias, definiciones o debates doctrinales e incluso las aportaciones que la jurisprudencia hace sobre este tema. De hecho, no existe un fundamento único que pueda resolver de forma pacífica todos los problemas a la vez, por lo que se han de tener en cuenta como principios básicos que informan el Derecho Penal, los de ultima ratio y de intervención mínima para garantizar la estabilidad y la paz social.

El Derecho Penal de menores ha de ser un derecho especializado, con celeridad en los procedimientos, donde se proteja el interés superior del menor como fin primordial, evitando la victimización secundaria que tanto perjudica su bienestar, donde las reformas de lege ferenda se basen en la confianza y la igualdad de derechos entre menores sin distinción, primando la responsabilidad y no la culpabilidad.

Dada la situación actual de excepcionalidad, donde la reforma ha quedado paralizada con respecto a la tramitación del Anteproyecto de Ley Orgánica de garantía integral de la libertad sexual, hemos de esperar que dicha reforma comprenda y recoja las necesidades sociales de manera clara y real, con respeto a la legalidad y protegiendo en última instancia el interés superior de todos los menores como víctimas especialmente vulnerables.

En definitiva, cualquier texto legislativo debe contener como principio fundamental, en general, el respeto al ordenamiento jurídico y debe clarificar, entre otros aspectos, el objeto, sujetos, bien/bienes jurídicos protegidos, etc., de modo que proporcione seguridad jurídica y confianza. 